\title{
Immunoglobulin Light-Chain Amyloidosis: From Basics to New Developments in Diagnosis, Prognosis and Therapy
}

\author{
Eli Muchtar Francis K. Buadi Angela Dispenzieri Morie A. Gertz \\ Division of Hematology, Mayo Clinic, Rochester, Minn., USA
}

\author{
Key Words \\ Diagnosis · Light-chain amyloidosis · Prognosis . \\ Recognition - Treatment
}

\begin{abstract}
Immunoglobulin amyloid light-chain (AL) amyloidosis is the most common form of systemic amyloidosis, where the culprit amyloidogenic protein is immunoglobulin light chains produced by marrow clonal plasma cells. AL amyloidosis is an infrequent disease, and since presentation is variable and often nonspecific, diagnosis is often delayed. This results in cumulative organ damage and has a negative prognostic effect. AL amyloidosis can also be challenging on the diagnostic level, especially when demonstration of Congo red-positive tissue is not readily obtained. Since as many as 31 known amyloidogenic proteins have been identified to date, determination of the amyloid type is required. While several typing methods are available, mass spectrometry has become the gold standard for amyloid typing. Upon confirming the diagnosis of amyloidosis, a pursuit for organ involvement is essential, with a focus on heart involvement, even in the absence of suggestive symptoms for involvement, as this has both prognostic and treatment implications. Details regarding initial treatment options, including stem cell transplantation, are provided in this review. AL amyloidosis management requires a multidisciplinary approach with careful pa-
\end{abstract}

tient monitoring, as organ impairment has a major effect on morbidity and treatment tolerability until a response to treatment is achieved and recovery emerges.

(c) 2016 S. Karger AG, Basel

\section{Introduction}

Amyloidosis is a generic idiom for heterogeneous protein misfolding syndromes in which a culprit protein assembles in a $\beta$-sheet structure, resulting in insolubility and subsequent tissue deposition, which ultimately leads to organ architecture disruption and dysfunction. While descriptions of patients with presumed amyloidosis can be traced back to 1639 [1], the term 'amyloid' was coined in 1838 for botanical purposes. Amyloid (Latin for 'starchlike'), was introduced to medicine by Rudolf Virchow in 1854 [2], reflecting his misconception of the amorphous extracellular deposits as starch based, but found later to be a fibrillary protein.

Currently, there are 31 known amyloidogenic proteins, each of which produces a distinct clinical syndrome [3]. This review will focus on systemic immunoglobulin amyloid light-chain (AL) amyloidosis, the most common form of systemic amyloidosis. Less common subtypes are reactive (AA) amyloidosis, senile systemic amyloidosis (SSA, wild-type transthyretin, TTR), TTR amyloidosis [mutant

\section{KARGER}

E-Mail karger@karger.com

www.karger.com/aha
(C) 2016 S. Karger AG, Basel

$0001-5792 / 16 / 1353-0172 \$ 39.50 / 0$
Morie A. Gertz, MD

Division of Hematology, Mayo Clinic

200 First Street, SW

Rochester, MN 55905 (USA)

E-Mail gertz.morie@ mayo.edu 
TTR, also known as familial amyloid polyneuropathy (FAP) or familial amyloid cardiomyopathy (FAC)], fibrinogen amyloidosis (AFib) and apolipoprotein A-I amyloidosis (AApoAI) [4]. Treatment is type dependent, emphasizing the importance of not only reaching a diagnosis of amyloidosis, but also having to confirm its correct type.

\section{AL Amyloidosis}

AL amyloidosis is a rare plasma cell proliferative disorder (PCPD) with an incidence of 3-9 per million personyears [5-7]. It is characterized by a clonal expansion of marrow plasma cells which produce kappa or lambda light chains (LCs), which upon accumulation aggregate and misfold in the form of amyloid. The plasma cell burden is usually small, with a median of 5-7\% bone marrow plasma cells (BMPCs) [8]. However, variation exists, which may reflect divergent thresholds for amyloid formation.

AL amyloidosis makes up a challenging PCPD on several levels. First, like other amyloid syndromes, recognition is often overlooked and diagnosis is delayed. The interval between symptom onset and diagnosis of the AL amyloidosis is longer in patients with a prior diagnosis of a PCPD (who are routinely monitored in the clinic) than patients without such a prior diagnosis [9]. Second, there is no single diagnostic test for this disease and establishment of the diagnosis requires a high index of suspicion followed by testing in sequence. Third, the disease poses a treatment challenge, as many patients present with advanced organ damage which impairs the ability to deliver effective treatment.

Recently, it has been demonstrated that patients with AL amyloidosis have evidence of a monoclonal protein in their sera years before the appearance of clinical disease [10]. This finding of a precursor disease state can increase the likelihood of early diagnosis, required for an improvement in patient outcome. This, however, requires techniques which will enable identification of those few patients among a larger pool of people with protein-secreting clonal disorders, who are 'amyloid-prone' or have early asymptomatic amyloid deposits. While there have been several attempts to predict the propensity of a protein to form amyloid $[11,12]$, none have been successful.

\section{Pathogenesis}

A number of excellent reviews on the pathogenesis of amyloidosis have been published in recent years [13-16]. Organ dysfunction in AL amyloidosis is not only a result of organ architecture disruption, but there is a direct cytotoxic effect of the amyloidogenic LCs $[17,18]$. This observation explains the rapid clinical improvement of successfully treated patients evidenced by biochemical organ recovery, before a reduction in the amyloid deposits at the affected organ(s) can occur. Additionally, persistence of amyloid deposits after successful treatment and organ recovery also supports LC toxicity as the cause of organ dysfunction $[19,20]$.

\section{Recognition}

Amyloidosis is often difficult to recognize as the presenting symptoms are insidious and nonspecific, and vary between patients. Patients typically present with fatigue, light-headedness and/or weight loss as well as signs and symptoms associated with the affected organ(s). Organ involvement may include progressive heart failure, nephrotic syndrome and/or renal failure, hepatomegaly and/or an increased level of serum alkaline phosphatase, autonomic and/or peripheral neuropathy, carpal tunnel syndrome, macroglossia and bleeding diathesis (in some patients due to factor X deficiency; fig. 1). Less common manifestations include, among others: jaw claudication [21], gastroparesis and intestinal pseudo-obstruction, polyarthralgia [22], muscle pseudohypertrophy [23], xerostomia [24] and alopecia [25]. The two most common involved organs are the kidneys and the heart $(60-80 \%$ of patients in most reports). Organ tropism has been suggested to be determined by the light-chain variable region [26-29], LC burden $[28,30]$ and tissue intrinsic features [30], but data so far are inconclusive [31].

Less than $10 \%$ of patients with AL amyloidosis copresent with symptomatic multiple myeloma (MM) and fulfill one or more of the CRAB criteria (hypercalcemia, renal failure not related to the amyloidogenic process, anemia and/or bony lesions) [8]. To a lesser extent, other secretory B cell neoplasms, such as Waldenström's macroglobulineia, chronic lymphocytic leukemia and nonHodgkin's lymphomas, can also lead to AL-type amyloidosis [32].

\section{AL Amyloidosis Screening}

When a patient presents with signs and symptoms suggestive of amyloidosis, screening tests for monoclonal protein production are warranted. This includes serum immunofixation and electrophoresis (IFE) as well as se- 
Fig. 1. Pinch hematoma in an AL amyloidosis patient with lymphoplasmacytic lymphoma. The patient presented with numerous small bruises over his chest wall, attributed by the patient to minor trauma (a). The next day he returned for a followup visit, revealing a large hematoma over his chest wall following a transthoracic echocardiogram performed as part of his workup (b). Factor X was within the normal range.

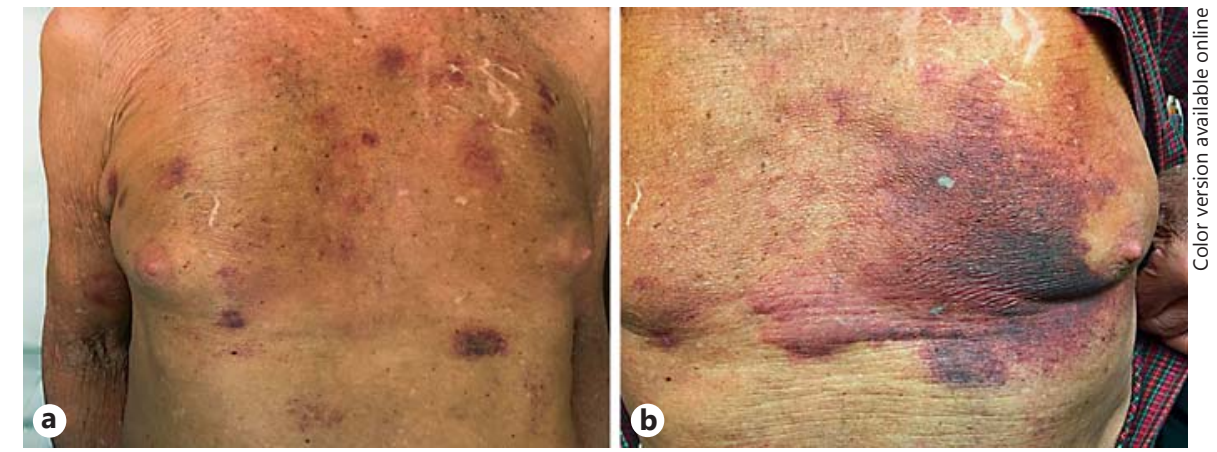

rum-free LC assay [33]. In a large series of $570 \mathrm{AL}$ amyloidosis patients, the elimination of the 24-hour urine IFE led to a decrease in the diagnostic sensitivity from 98.1 to 97.1\% [34], indicating that the need for urine IFE in AL amyloidosis screening is minimal. If tests indicate the presence of a monoclonal protein, further diagnostic work-up is needed. If all tests for monoclonal protein are negative, then AL amyloidosis is very unlikely ( $2 \%)$, and unless clinical suspicion remains high no further workup for PCPD is indicated. Other amyloid syndromes should be considered. Gene sequencing for hereditary amyloidosis is organ oriented, as each hereditary syndrome has a distinct 'organ signature'.

\section{Diagnosis}

The diagnostic backbone of amyloidosis is based on three fundamental requirements: (1) histopathological diagnosis with amyloid typing, (2) determination of whether the disorder is systemic or localized and, if systemic, (3) evaluation for disease extent. The initial source for a pathological diagnosis of systemic disease is a subcutaneous fat aspiration (SFA) coupled with bone marrow biopsy (the latter being performed as part of the PCPD workup). These two procedures are easily performed, carry little risk to the patient and have a combined diagnostic sensitivity of $85 \%[35,36]$, making them an excellent initial option for pathological confirmation. A video on the fat pad aspiration procedure is available [37]. For the remaining $15 \%$ of patients negative for amyloid in SFA and bone marrow biopsy, a thorough reexamination of 3 slides by two experienced pathologists has been shown to increase sensitivity [38] and could be considered. Alternatively, biopsy of one of the affected organ(s) will increase the diagnostic yield to $90-95 \%$ [38, 39], but must be weighed against the risks of a more in- vasive procedure. Another alternative is to perform a biopsy of a labial salivary gland, a minimally invasive procedure that can spare more than half of SFA-negative patients from the need to undergo a biopsy of the affected organ [40].

The histopathological diagnosis of amyloidosis is based on the affinity of 'Congo red' dye to amyloid [13], independent of its type. Nevertheless, Congo red avidity must be associated with apple green birefringence. This dye intercalates with the amyloid fibrils, and under polarization microscopy a vivid green birefringence appears, which illustrates the organized ultrastructure of the fibrils and confirms the presence of amyloid deposits.

As treatment is exclusively type driven, amyloid typing is an inseparable part of the pathological evaluation. Traditional typing by immunohistochemistry staining can be misleading due to high background staining caused by serum contamination and formalin-induced epitope loss [41]. Additionally, immunohistochemistry may lack sensitivity due to c-terminus variability of the LCs. Therefore, lack of LC immunostaining does not exclude AL amyloidosis [42]. Conversely, the presence of a monoclonal protein does not necessarily prove AL amyloidosis, as monoclonal gammopathy of unknown significance is a relatively common finding in people over the age of 50 years [43] and, therefore, may be a coincidental finding. Indeed, $9.7 \%$ of patients with non-AL amyloidosis were reported to have a monoclonal protein [44]. Proper classification is best achieved by mass spectrometry (MS) sequencing, which is the standard for amyloid typing, with nearly $100 \%$ sensitivity [41]. The assay is performed on Congo red-positive tissues (including formalin-fixed paraffin-embedded samples) and involves laser microdissection of a deposit, tryptic proteolysis followed by protein sequencing by liquid chromatography and MS to sequence protein subunits (fig. 2). This method also allows identification of rare or unknown variants of amyloido- 


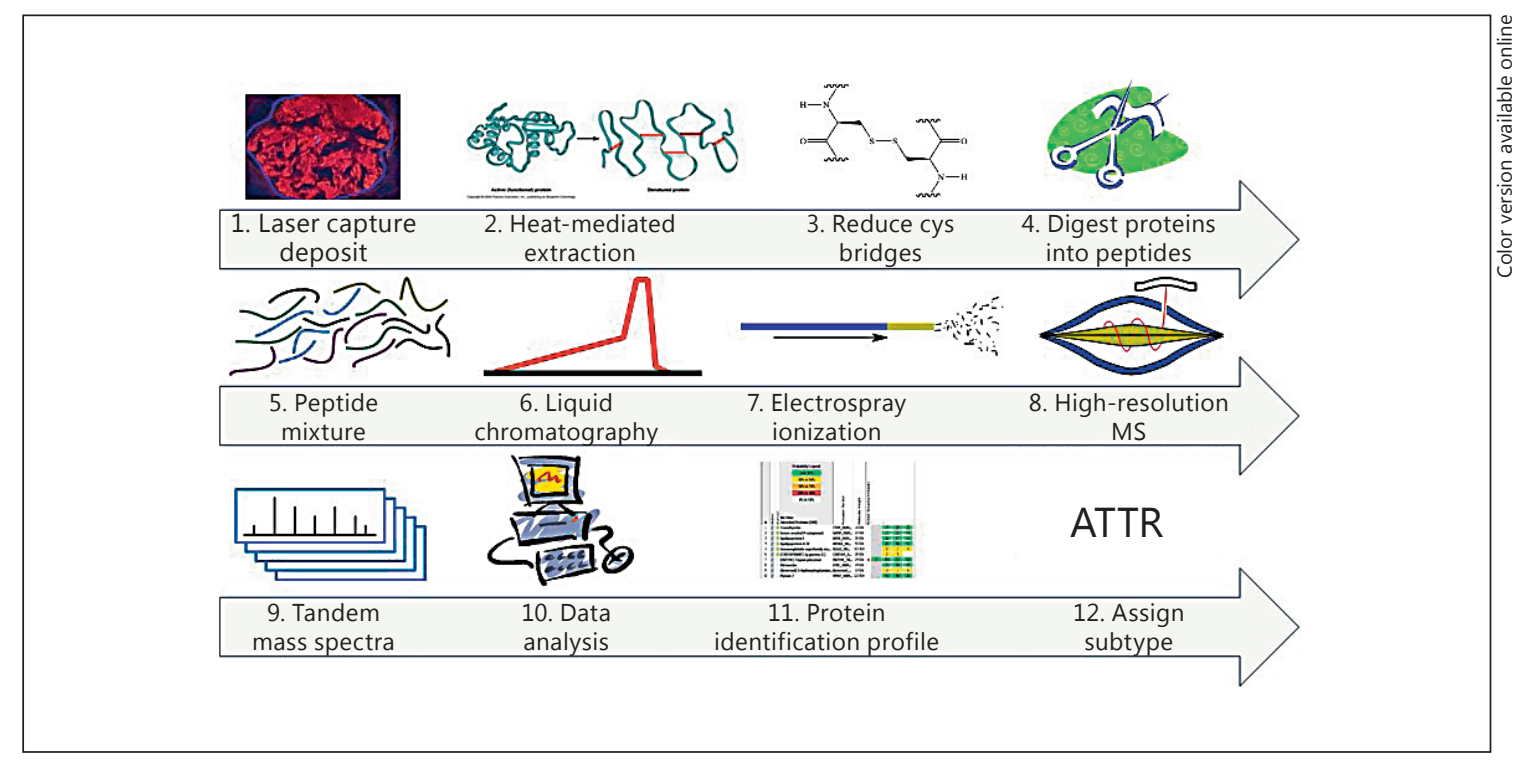

Fig. 2. Amyloid subtyping workflow for formalin-fixed paraffinembedded specimens. (1) Laser capture microdissection of Congo red-positive fluorescent amyloid deposits - three microdissections per sample, each encompassing an area of $60,000 \mu \mathrm{m}^{2}$. (2) Protein denaturation and lysis of cross-links from formalin fixation. (3) Reduction of cysteine (cys) bridges. $(4,5)$ Digestion of proteins into peptides using trypsin (cuts at lysine $\mathrm{K}$ and arginine $\mathrm{R}$ sites). (6) The peptide mixture is subjected to nanoflow liquid chromatography (Eksigent). $(7,8)$ Electrospray ionization is followed by high-resolution MS on an LTQ orbitrap or LTQ velos mass spec- trometer. $(9,10)$ The tandem mass spectra are matched against protein sequence databases (Swissprot and locally curated) using 3 search engines (Mascot, X!Tandem and Sequest). (11) Peptide identifications are assembled into protein sequences using Scaffold software (Proteome Software) - at least 2 peptide matches with 95\% confident identification. (12) The amyloid subtype is assigned based on the amyloid-specific peptide that had the largest number of peptide 'hits'. We would like to thank Dr. Paul Kurtin for granting us the permission to reproduce this figure. sis, which are hard to diagnose with other available typing methods. MS requires a trained and equipped laboratory for this purpose; if this is not available, amyloid typing can rely on immunohistochemistry $[45,46]$ or immunoelectron microscopy [47], but should be cross-validated with both clinical and laboratory data.

\section{Disease Extent}

Once a diagnosis is established, the disease extent needs to be determined. Although recognized in less than $10 \%$ of patients [48], a positive Congo red tissue with no evidence for systemic disease may be encountered. Localized amyloidosis is typically seen in mucosal surfaces, such as the gastrointestinal tract (GIT), urinary tract, breasts, lungs and upper airways, as well as the skin [49]. It probably stems from a localized production of monoclonal LCs, and is thought to involve local amyloid phagocytic processing which provides the amyloidogenic properties of the LCs [50]. A diagnosis of localized AL amyloidosis is usually made after tissue sampling for symptoms induced by local deposition, although an incidental diag- nosis can also occur. In these patients, SFA and bone marrow biopsy are negative for amyloid deposits with a lack of systemic symptoms. It is important to recognize this entity, as its course is usually benign and requires primarily localized measures [51] or observation only.

In systemic amyloidosis, the extent of organ involvement should be sought. As cardiac involvement is the most important organ-related prognostic factor $[52,53]$, assessment of cardiac function is paramount.

\section{Cardiac Involvement}

Cardiac biomarkers, which include cardiac troponin $\mathrm{T}$ and N-terminal pro-brain natriuretic protein (NT-proBNP; or alternatively, BNP), should be assessed in all patients owing to its high sensitivity for cardiac involvement $[54,55]$ as well as its prognostic value. Cardiac imaging should also be obtained. Echocardiography remains a valuable and sensitive tool for the assessment of cardiac amyloidosis. The classical imaging features suggesting cardiac involvement are a 'speckled pattern' of the myocardium and thickened myocardium seen on echocar- 
Fig. 3. CMR imaging. a Early gadolinium phase; note the asymmetric hypertrophy of the septum compared with the ventricle free wall. b Short-axis view: transmural LGE (arrow) typically seen in AL amyloidosis. LV = Left ventricle; RV = right ventricle.
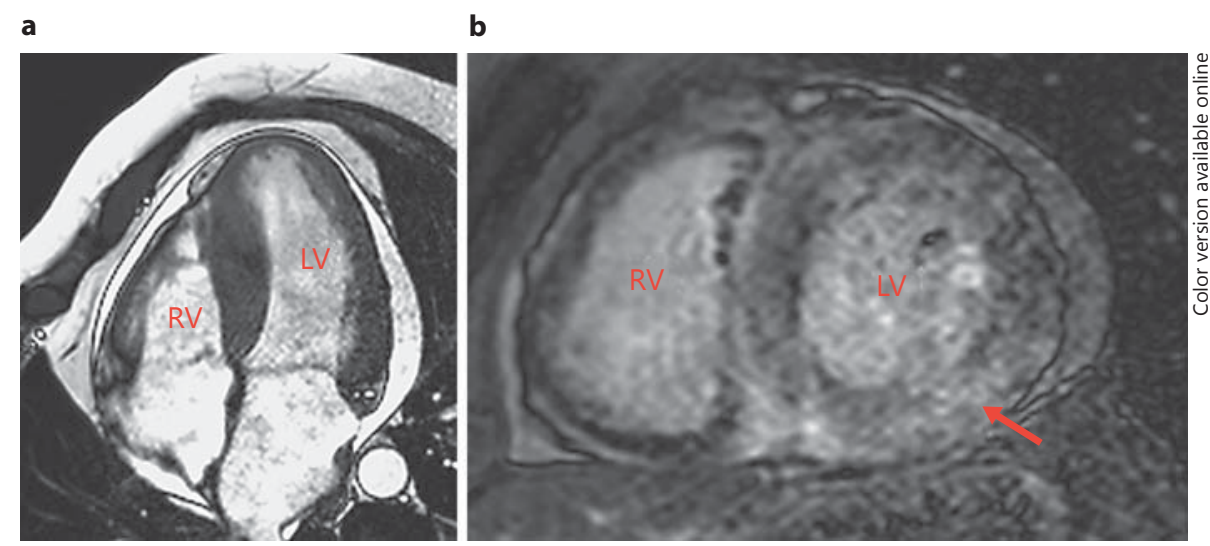

diography, although all portions of the heart can be involved [56-58]. Current diagnostic imaging criteria for cardiac involvement include a mean left ventricular wall thickness (septum plus posterior wall thickness divided by 2) greater than $12 \mathrm{~mm}$ in the absence of alternative explanations [59]. However, the wall measure may remain normal, despite significant cardiac dysfunction. The reported incidence of this 'nontraditional' presentation ranges from 3\% [60] to a third of cardiac involvement [61], although in the former study only patients with an ejection fraction $\leq 40 \%$ were included.

Cardiac dysfunction is primarily diastolic, as heart failure symptoms often develop with a still preserved (or only mildly impaired) ejection fraction. However, Dopplerbased strain echocardiography is a sensitive method for early recognition of cardiac impairment in AL amyloidosis. This method assesses the ability of the myocardium to shorten upon contraction in a longitudinal plane. A longitudinal systolic strain of the basal anteroseptal segment that is less negative than or equal to $-7.5 \%$ was found to be an independent negative predictor of survival [62].

In addition to echocardiography, cardiac magnetic resonance (CMR) is an excellent tool for the diagnosis of cardiac amyloidosis. Late gadolinium enhancement (LGE) is the hallmark feature (fig. 3), reflecting interstitial edema induced by the amyloid deposits, but has also been linked to ischemic-induced fibrosis [63]. LGE is usually observed throughout the myocardium, either transmural or subendocardial, but nonglobal patterns can also be detected. Is has also been shown that LGE correlates with histological, laboratory and clinical parameters [64], and has prognostic value. Transmural LGE was associated with advanced cardiac involvement and inferior survival [65].

Overall, CMR is a valuable tool in cardiac amyloidosis due to its high sensitivity and specificity in detecting heart involvement compared with echocardiography. However, gadolinium administration may produce a devastating nephrogenic systemic fibrosis in patients with impaired kidney function, which is common in AL amyloidosis. Furthermore, as strain echocardiography has a powerful prognostic impact and is easily obtained, we recommend echocardiography with strain imaging for all patients, with the addition of CMR when cardiac involvement remains in question.

\section{Other Organ Involvement Work-Up}

Renal involvement is assessed by measuring creatinine (or estimated glomerular filtration rate, eGFR) and proteinuria. Traditionally, 24-hour collection for urine protein was the gold standard, but spot albumin-to-creatinine ratio may suffice [66]. The diagnostic criterion for renal involvement is excretion of $>0.5 \mathrm{~g}$ of albumin in a 24-hour urine collection. However, rarely, patients can present with renal insufficiency and minimal proteinuria [67], suggesting interstitial/vascular-limited amyloidosis [68]. In such cases, a renal biopsy is justifiable to clarify the cause of the renal failure.

Hepatic involvement is assessed by measuring serum alkaline phosphatase and liver span by imaging. The diagnostic criterion defines involvement if the liver span is above $15 \mathrm{~cm}$ or serum alkaline phosphatase is more than 1.5 times the institutional upper limit of normal. Both liver measures can be abnormal in the presence of right heart failure. Basic testing for autonomic dysfunction includes orthostatic blood pressure measurement and evaluation for the loss of beat-to-beat variability on resting electrocardiogram [69].

Serum amyloid P (SAP) is a glycoprotein which constitutes $10-15 \%$ of the amyloid deposits, regardless of its source. A radiolabeled SAP scan with ${ }^{123} \mathrm{I}\left({ }^{123} \mathrm{I}-\mathrm{SAP}\right)$ is a sensitive method to detect visceral deposition of amyloid, 
Table 1. The revised Mayo staging system for AL amyloidosis

\begin{tabular}{lll}
\hline $\begin{array}{l}\text { Assigned } \\
\text { stage }\end{array}$ & $\begin{array}{l}\text { Relative proportion of } \\
\text { patients in the primary } \\
\text { cohort, \% }\end{array}$ & $\begin{array}{l}\text { Median survival, } \\
\text { months }\end{array}$ \\
\hline 1 (0 points) & 25 & 94.1 \\
2 (1 point) & 27 & 40.3 \\
3 (2 points) & 25 & 14 \\
4 (3 points) & 23 & 5.8 \\
\hline
\end{tabular}

A score of 1 is assigned for each of three variables: cardiac troponin $\mathrm{T} \geq 0.025 \mathrm{ng} / \mathrm{ml}$, NT-ProBNP $\geq 1,800 \mathrm{pg} / \mathrm{ml}$ and $\mathrm{dFLC} \geq 18$ $\mathrm{mg} / \mathrm{dl}$.

even in tissues not considered to be clinically involved [70]. It has limited value in gastrointestinal and nervous system assessment, and is unable to detect cardiac involvement. Therefore, this imaging has a limited role in diagnosis and response assessment.

\section{Prognosis}

$\mathrm{AL}$ amyloidosis carries the poorest prognosis of systemic amyloidosis syndromes. In the absence of treatment, the median survival is only 8 months [71] compared with 24-66 months in TTR cardiac amyloidosis [72]. This might be a result of a direct toxic effect of the LCs in AL amyloidosis [73], or the more widespread organ involvement associated with AL amyloidosis compared with other amyloidosis types. As AL amyloidosis affects vital organ function, and as diagnosis is often delayed, the prognosis often depends on the 'deposition burden', with a primary focus on whether the heart is involved and to what extent.

The most common prognostic scoring system in use is the Mayo staging system [74], which was revised in 2012 [75] (table 1). This staging system originally included the soluble cardiac biomarkers NT-proBNP and cardiac troponin $\mathrm{T}$, whereas in the revised system the difference between involved and uninvolved LCs (dFLC) was added. The validity of the revised staging system lies in its large cohort of patients (over 800), simplicity, its reproducibility and the introduction of the alternative of BNP instead of NT-proBNP.

dFLC is an indirect measure of tumor burden and, not surprisingly, is the most significant variable as it is the potentially direct cause of tissue damage and organ dysfunction and is widely available. Interestingly, both car-

Immunoglobulin AL Amyloidosis Review diac biomarkers, troponin T and NT-proBNP are independent of each other as prognostic factors, probably as these biomarkers measure different effects of amyloid deposition in the myocardium. While troponin measures myocyte damage, NT-proBNP is a measure of myocyte stretch and, therefore, a marker for heart failure. Both biomarkers are elevated in renal failure, which can reduce its value. It has been suggested that higher cutoffs of BNP and NT-proBNP should be used in the setting of renal failure. Only BNP retained predictive value in patients with an eGFR below $15 \mathrm{ml} / \mathrm{min}$ [76]. High-sensitivity troponin $\mathrm{T}$ has also been shown to have independent prognostic significance [54, 77].

Additional prognostic factors that have been described include: multiorgan involvement $[78,79] ; \geq 10 \%$ BMPCs [8]; abnormal cytogenetics [t $(11 ; 14)$ and trisomies] [80]; systolic blood pressure $<100 \mathrm{~mm} \mathrm{Hg}$ [81]; performance status $(\mathrm{ECOG}>2)$ [82]; serum uric acid $>8 \mathrm{mg} / \mathrm{dl}[83,84]$; body mass index $(\mathrm{BMI})<22$, and unintentional weight loss $>10 \%$ in 6 months [85].

Emerging prognostic biomarkers in $\mathrm{AL}$ amyloidosis include: osteopontin, a potential biomarker of cardiac injury and biomechanical strain [86]; soluble suppression of tumorigenicity 2, a marker of cardiac remodeling and fibrosis [87], and human placental growth factor, a marker for endothelial dysfunction [88].

\section{Treatment}

\section{Defining Treatment Goals}

$\mathrm{AL}$ amyloidosis is a distinct PCPD in terms of treatment goals. First, the prime goal is improvement in patient survival. However, since treatment-related toxicity may be high as a result of patient frailty and vital organ dysfunction, careful treatment selection is warranted to maintain a delicate balance between disease phenotype, anticipated response rate and treatment toxicity. Second, in terms of disease burden, the goal is to achieve a rapid and maximal reduction of the pathogenic LCs. While similar to the treatment goal in MM, in AL amyloidosis a maximal reduction of the circulating LC is more than a marker of response, but is mandatory to prevent further organ damage. Therefore, the response goal in AL amyloidosis is more stringent than in MM, meaning that at least a near complete reduction of the involved LC is warranted in most patients. Such a deep response can be hard to achieve, especially if treatment is not intensive. A third goal, apart from the reduction of the pathogenic LCs, is the recovery of all affected organs. 
Table 2. HR and OR criteria

\begin{tabular}{|c|c|}
\hline \multicolumn{2}{|l|}{$H R$} \\
\hline CR & $\begin{array}{l}\text { Negative serum and urine immunofixation electrophoresis and normal serum } \\
\text { FLC ratio }\end{array}$ \\
\hline VGPR & $\mathrm{dFLC}<4 \mathrm{mg} / \mathrm{dl}$ \\
\hline $\mathrm{PR}$ & dFLC decrease $\geq 50 \%$ \\
\hline No response & Less than PR \\
\hline \multicolumn{2}{|l|}{ OR } \\
\hline Cardiac response & $\begin{array}{l}\text { Decrease in NT-proBNP by }>30 \% \text { and } 300 \mathrm{pg} / \mathrm{ml} \text { (if baseline NT-proBNP } \\
>650 \mathrm{pg} / \mathrm{ml} \text { ), or a } \geq 2 \text {-point decrease in NYHA class (if baseline NYHA class } \\
\text { III or IV) }\end{array}$ \\
\hline Renal response & $\begin{array}{l}30 \% \text { decrease in proteinuria or a drop below } 0.5 \mathrm{~g} / 24 \mathrm{~h} \text {, each coupled in the } \\
\text { absence of renal progression, defined as a }>25 \% \text { decrease in eGFR }\end{array}$ \\
\hline Hepatic response & $\begin{array}{l}50 \% \text { decrease in abnormal alkaline phosphatase value or decrease in } \\
\text { radiographic liver size by at least } 2 \mathrm{~cm}\end{array}$ \\
\hline Nervous system response & Improvement in electromyogram nerve conduction velocity \\
\hline
\end{tabular}

A uniform response definition has been established $[59,89]$, with two response components to consider: hematological response (HR), which corresponds to the degree of reduction in the amyloidogenic LC, and organ response (OR), which represents the improvement in organ function (table 2).

The HR criteria define four levels of response: complete response (CR; negative serum and urine and normal FLC ratio; no need for confirmatory bone marrow evaluation); very good partial response (VGPR; $\mathrm{dFLC}<40 \mathrm{mg} / \mathrm{l})$; partial response (PR; dFLC decrease $>50 \%$ ), and no response (less than PR). The achievement of at least VGPR should be the treatment goal, as it correlates with a significant improvement in survival compared to a PR level [89]. This is also supported by the fact that the percent reduction of involved LC from baseline was not predictive of overall survival, while the achievement of absolute low levels was [90].

OR criteria are defined for the 4 major relevant organs (heart, kidney, liver, nervous system) [59] and have been updated for heart [89] and kidney involvement [91]. The details on each OR can be viewed in table 2. The deeper the HR the higher the likelihood of achieving an OR [53, $78,90-93$ ]. The kinetics between HR and OR can be seen in a selected cohort of $313 \mathrm{AL}$ amyloidosis patients who achieved normalization of the FLC ratio (nFLCr) following treatment. Seventy-four percent of these patients had at least one OR. The median time to first OR was 2.1 months from the time of nFLCr. Additionally, achieving early OR within 1 year of nFLCr predicted better survival compared to patients with nFLCr achievement but who failed to achieve early OR [93].
Table 3. Mayo's transplant eligibility criteria for AL amyloidosis

Physiologic age $\leq 70$ years

Performance score $\leq 2$

NYHA class I/II

Cardiac troponin $\mathrm{T}<0.06 \mathrm{ng} / \mathrm{ml}$

Systolic blood pressure $>90 \mathrm{~mm} \mathrm{Hg}$

Creatinine clearance $\geq 30 \mathrm{ml} / \mathrm{min} / 1.73 \mathrm{~m}^{2}$

(unless undergoing long-term dialysis)

Less than 3 organs significantly involved

\section{Initial Treatment}

Treatment options for AL amyloidosis follow options available for MM, with toxicity-driven adjustments. However, amyloid-targeted treatment alternatives have emerged, as will be discussed in the Novel Therapies section below. The Mayo Stratification of Myeloma and Risk-Adapted Therapy (mSMART) nonstudy treatment algorithm can be viewed in figure 4 .

\section{Assessing the Risk of Treatment-Related Toxicity} (Risk-Adapted Approach)

As in MM, treatment is guided by eligibility to undergo autologous stem cell transplantation (ASCT). Eligibility is based on the patient's general fitness and organ function, with a main focus on cardiac performance. The Mayo eligibility criteria for ASCT are presented in table 3 [92]. With better patient selection and better supportive care, a reduction of early posttransplant mortality was observed by the two major single-center reports on ASCT in 


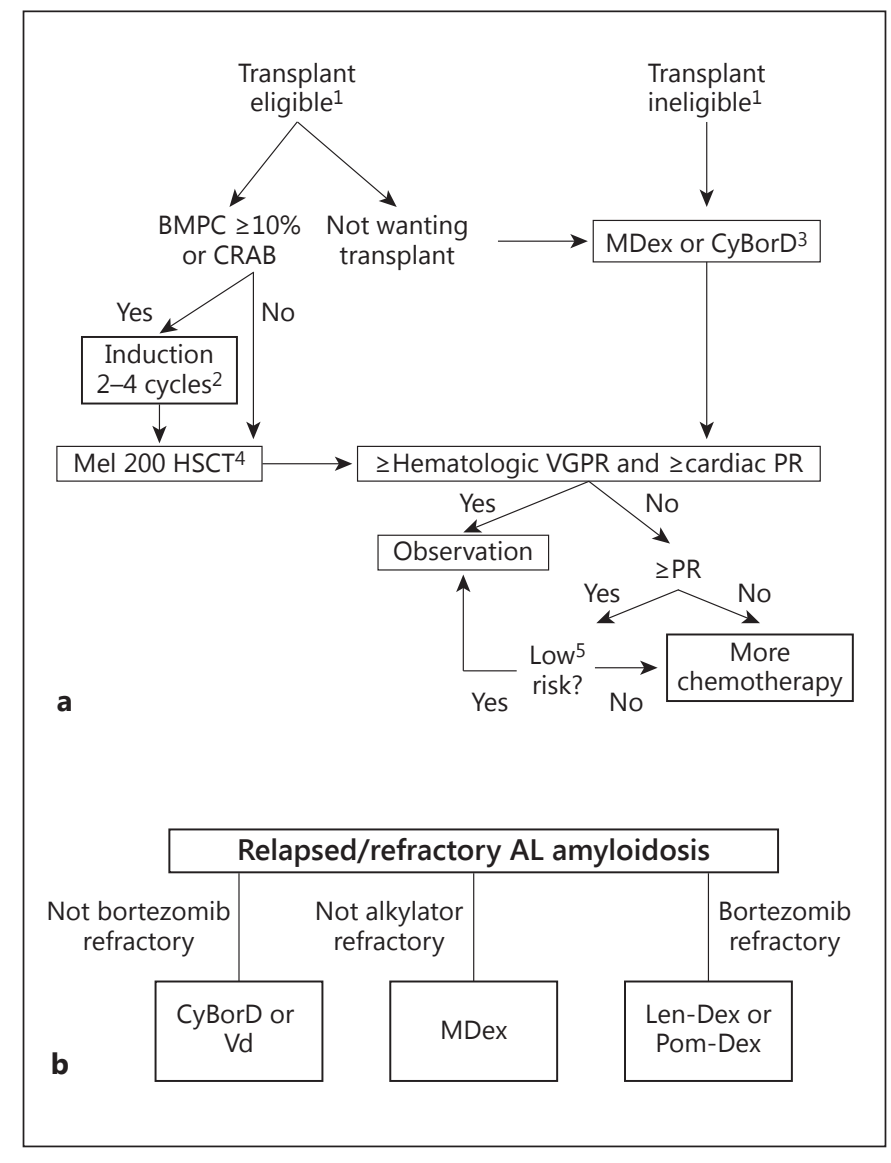

Fig. 4. a Newly diagnosed AL amyloidosis. ${ }^{1}$ Criteria for ASCT: troponin $\mathrm{T}<0.06$ and $\mathrm{BP} \geq 90 \mathrm{~mm} \mathrm{Hg} .{ }^{2}$ Induction also if there is a delay in proceeding to ASCT or as clinically indicated. ${ }^{3}$ If the response at 2 months is less than PR or if there is NT-proBNP progression, consider changing therapy. ${ }^{4}$ For age $>70$ years or creatinine clearance $<30 \mathrm{ml} / \mathrm{min} / 1.73 \mathrm{~m}^{2}$, use melphalan (Mel) $140 \mathrm{mg} /$ $\mathrm{m}^{2}$. HSCT $=$ Hematopoietic stem cell transplant. ${ }^{5}$ Mayo 2004 stage I or Mayo 2012 stage I or II. b mSMART.org guidelines for the treatment of AL amyloidosis (off study). Vd = Bortezomib dexamethasone; Len = lenalidomide; Pom = pomalidomide.

AL amyloidosis, the first from Boston University [94] and the second from the Mayo clinic [95]. Both trials reported a decline in 100-day mortality compared with an earlier period, with current figures at 5.6 and 7\%, respectively. With a refinement in eligibility criteria (NT-proBNP $<5,000 \mathrm{pg} / \mathrm{ml}$ and cardiac troponin $\mathrm{T}<0.06 \mathrm{ng} / \mathrm{l}$ ), there was a further decline in 100 -day mortality to $1.1 \%$ [96], a rate which is comparable to that seen in MM patients who undergo ASCT [97]. These single-center results have been confirmed in a study from the registry of the Center for International Blood and Marrow Transplant Research (CIBMTR) [98]. This report, the largest to date, encom- passing 1,536 AL amyloidosis patients who underwent ASCT at 134 centers in the USA and Europe, showed a significant reduction in 100-day mortality from 20 to 11 to 5\% between the periods 1995-2000, 2001-2006 and 2007-2012, respectively. Another European report also suggests that outcome depends on a center's ASCT experience [99].

\section{Autologous Stem Cell Transplantation}

The use of ASCT in AL amyloidosis is not as common as in younger MM patients, and is in use more frequently in the USA than in most European countries. The first feasibility report on ASCT in AL amyloidosis came from the Boston University in the mid-1990s [100], which opened a new treatment era for AL amyloidosis.

\section{Pros and Cons of ASCT}

The benefit of ASCT comes from both the rapid reduction of the involved LC as well as a high rate of HR and OR. In a study of 454 patients, $80 \%$ achieved HR following ASCT and 40\% gained CR [101]. In terms of survival, the largest outcome study in transplanted patients reported a current 5-year survival at 77\% [98]. Even with prolonged follow-up, survival remains high, with $43 \%$ of patients who undergo ASCT surviving more than 10 years [79]. When comparing the outcome of transplanted patients between $\mathrm{AL}$ amyloidosis and MM, more AL amyloidosis patients achieve CR (40 vs. 29\%), and their median OS is significantly higher (113 vs. 59.5 months) [101]. The greatest survival difference was noticed among those who attained CR, as MM patients in this subgroup had a nearly 5 -fold risk of death compared to their AL amyloidosis counterparts. These results are not attainable by conventional chemotherapy, and therefore every patient eligible for ASCT should be offered this procedure. Unfortunately, only $20-25 \%$ of AL amyloidosis patients are considered transplant eligible.

ASCT application in AL amyloidosis is restricted for two reasons. First, this technique is associated with significant toxicity, mainly in cardiac amyloidosis and patients with multiorgan involvement. Second, data in favor of its use derive from uncontrolled studies, while there is no evidence from randomized control trials (RCTs) to support its selection. In fact, the only RCT that addressed the role of ASCT in AL amyloidosis showed an inferior outcome to ASCT over conventional chemotherapy [102]. That trial compared ASCT with oral melphalandexamethasone (MDex) and, although response rates were comparable, survival was inferior in the ASCT arm. However, this was a small-scale trial with high TRM at 
$24 \%$, far higher than the reported 5\% TRM in studies with stringent patient selection. New nonintensive regimens, as will be discussed, further limited more widespread use of ASCT.

\section{Stem Cell Mobilization}

Although considered a safe procedure in MM, stem cell collection in AL amyloidosis using granulocyte colonystimulating factor (G-CSF) can be associated with significant morbidity and even rare reports of mortality [103]. Major complications associated with this procedure include fluid overload, weight gain, cardiac arrhythmias, and cardiopulmonary collapse and predominantly occur in patients with cardiac involvement. It is assumed to be a form of capillary leak syndrome triggered by the G-CSF. Moreover, the presence of autonomic dysfunction can complicate stem cell harvest, with hypotension that can develop during collection; $10 \%$ of patients who undergo stem cell collection need a delay of 1 month or longer before proceeding to the transplant in order to recover from fluid retention [35].

Plerixafor, a reversible antagonist of CXCR4, has been used successfully with G-CSF in stem cell mobilization in AL amyloidosis [104, 105]. The yield of CD34+ cell dose was higher when plerixafor was used with G-CSF and with less apheresis procedures, but collection with these two agents was no safer than with the use of G-CSF alone.

\section{Dose of Melphalan}

Similar to MM, the traditional conditioning regimen is melphalan at a dose of $200 \mathrm{mg} / \mathrm{m}^{2}$. However, an attenuated dose $\left(100-140 \mathrm{mg} / \mathrm{m}^{2}\right)$ is commonly used, due to older age, multiorgan damage, or for single organ cardiac or kidney impairment, in order to reduce toxicity associated with full-dose melphalan. In the CIBMTR study [98], less than half of patients received full-dose melphalan $\left(\geq 180 \mathrm{mg} / \mathrm{m}^{2}\right)$, and there was a trend towards the more frequent use of attenuated doses in the 2007-2012 period compared with the $2001-2006$ period ( 64 vs. $49 \%$, respectively). An attenuated dose of melphalan is associated with a reduced response rate and survival compared to full-dose melphalan $[53,106]$, but toxicity is similar.

\section{Upfront ASCT versus Prior Induction}

Several trials have looked into the role of induction chemotherapy before proceeding to ASCT. In a randomized trial, two courses of melphalan-prednisone before ASCT resulted in a similar response and survival compared with the ASCT-only arm. Moreover, fewer patients in the induction arm proceeded to ASCT as a result of progression during the induction phase [107]. In a more recent randomized trial, prior induction with 2 cycles of bortezomib and dexamethasone was compared to ASCT alone in 56 patients. The induction arm showed an improved response rate ( 86 vs. $53 \%$ at 12 months), higher CR rate (70 vs. $35 \%$ at 2 years) and better OS ( 95 vs. $69 \%$ at 2 years) compared with the ASCT-only arm [108]. In our experience, patients with less than 10\% BMPCs can proceed to frontline ASCT, whereas those with $>10 \%$ BMPCs are treated with induction prior to ASCT [92]. It is reasonable in patients with poor organ function to proceed with induction chemotherapy in anticipation of improved organ function, which then will allow them to be eligible for full-dose melphalan ASCT.

\section{Consolidation Treatment following ASCT}

The strategy of consolidation following transplantation in an attempt to improve outcome was assessed in several trials. In a phase II trial, patients not achieving a CR following ASCT received 6 cycles of bortezomibdexamethasone. Of the 21 patients evaluable, 18 (86\%) had improvement in their HR, with two thirds of them reaching a CR from PR or stable disease. Most responses occurred within the first consolidation cycle. Grade 3-4 adverse events (AEs) were limited, except for $40 \%$ grade 3 thrombocytopenia. One patient with advanced cardiac disease died during consolidation [109]. With the lack of high-quality data, it is reasonable to offer limited consolidation cycles if at least a VGPR is not achieved following ASCT.

\section{Conventional Chemotherapy}

Most AL amyloidosis patients cannot tolerate highdose chemotherapy due to age and/or significant organ compromise. As treatment-related toxicity is high with conventional chemotherapy, treatment schedule and dosing should be individualized based on age, frailty, performance status and cardiac function and regimen tolerability. A risk-adapted strategy has been shown to improve 1-year survival in bortezomib-dexamethasonetreated patients [110]. HR rates to various regimens do not exceed $80 \%$ in most trials. Therefore, treatment failure may occur and a switch to an alternative regimen is warranted to prevent further organ damage. The point at which such a decision is made has not been verified but is dependent on the patient's condition. Those who have significant organ compromise and/or high-risk disease should be switched to an alternative regimen within $2 \mathrm{cy}-$ cles of treatment if at least a PR is not achieved. For lowrisk patients with a good physical condition and pre- 
served organ function, this decision can be postponed to the end of the third cycle.

The optimal duration of treatment with conventional chemotherapy has not been verified in clinical trials, and most trials schedule 8-12 treatment cycles. A long-term maintenance phase following induction treatment was proposed by a few trials $[111,112]$, but the clinical benefit is unclear and should be evaluated in future trials. Unlike $\mathrm{MM}$, response rates among treatment-naïve and relapsed patients do not differ considerably, which might reflect the selection of relapsed patients since patients with advanced disease die early.

\section{Alkylator-Based Regimens}

Alkylators combined with glucocorticoids formed the treatment backbone for AL amyloidosis for several decades. Melphalan and prednisone proved superior to colchicine in two RCTs in terms of survival $[71,113]$. However, the comparator was ineffective, OR was infrequent and patients with cardiac amyloidosis did not benefit, with a median survival of several months.

In 2004, an Italian phase 2 trial assessing MDex (a melphalan/high-dose dexamethasone combination) showed this regimen to be active with an HR rate of $67 \%$ (CR $33 \%$ ), an OR rate of $48 \%$ and an acceptable toxicity profile of grade 3 or above AEs of $11 \%$ [114]. In an extended follow-up report, the median survival was 61 months [115]. MDex has become a standard of care for AL amyloidosis, to which all newer regimens are compared. The RCT comparing MDex to ASCT [102] confirmed the MDex results and demonstrated a survival benefit for MDex over ASCT. Subsequent single-arm trials evaluating MDex showed an inferior response rate [116] and/or inferior survival $[117,118]$ compared with the pivotal MDex trial, but a higher proportion of patients with cardiac involvement and lack of staging data preclude a true comparison between these trials. Nevertheless, it appears that MDex is not sufficient to overcome the poor prognosis associated with advanced cardiac amyloidosis.

\section{Novel Agent-Based Treatment}

Proteasome Inhibitor-Based Regimens. Proteasome inhibitors are characterized by a rapid treatment response, making them appealing agents for this disease. Bortezo$\mathrm{mib}$, as the first-in-class proteasome inhibitor, has been the most explored agent, but as with other agents studied in this rare disease, most published data come from uncontrolled studies, and the ability to make solid conclusions is limited.

Immunoglobulin AL Amyloidosis Review
In a phase I/II trial, single-agent bortezomib was investigated in a relapsed setting in two schedules, $1.6 \mathrm{mg} /$ $\mathrm{m}^{2}$ once weekly and $1.3 \mathrm{mg} / \mathrm{m}^{2}$ biweekly [119]. An HR was seen in $\sim 70 \%$ of patients in both groups, with a CR rate higher in the once-weekly schedule (37\%) compared with the twice-weekly schedule (24\%). The median time to best response was 3.2 months in the once-weekly regimen compared to 1.2 months in the twice-weekly regimen. The toxicity profile favored the once-weekly schedule with fewer grade 3-4 AEs (50 vs. 79\%, respectively). Furthermore, 2 patients in the twice-weekly schedule died, possibly related to bortezomib. Overall, the onceweekly schedule is favored both for response and toxicity. As this trial excluded patients with New York Heart Association (NYHA) class III-IV, caution should be used in this group of patients when using this agent. It is advisable to use lower bortezomib doses in this group $(0.7-1 \mathrm{mg} /$ $\mathrm{m}^{2}$ once weekly), as bortezomib in higher doses was linked to worsening heart failure [120].

Bortezomib was studied in combination with dexamethasone with or without an alkylator. The most reported regimen is bortezomib in combination with dexamethasone and cyclophosphamide (CyBorD), following its use in MM management as well as an initial report in AL amyloidosis showing a response rate in $94 \%$ of patients (71\% CR) [121]. The largest report on this combination comes from two large European amyloidosis centers that retrospectively analyzed 230 newly diagnosed patients [52]. HR was seen in $60 \%$ of patients, with $23 \%$ achieving CR. Patients with advanced cardiac disease (defined by cardiac troponin $\mathrm{T}>0.035 \mathrm{ng} / \mathrm{ml}$ and NT-pro$\mathrm{BNP}>8,500 \mathrm{ng} / \mathrm{l}$ ) had a lower response compared with patients who did not meet these criteria (42 vs. $64-77 \%$, respectively). However, in a 3-month landmark analysis, of the 31 patients with advanced cardiac disease, those who achieved at least a PR had a better survival compared with those with no HR (median survival 26 vs. 6 months, respectively; $\mathrm{p}<0.001)$.

Results of a phase 3 RCT comparing MDex with bortezomib and melphalan, dexamethasone (BMDex) are yet to be reported in a manuscript form, while interim analysis shows only a trend towards improved HR with BMDex compared to MDex ( 75 vs. $55 \%, p=0.07$ ), with no significant difference in survival [122]. Other proteasome inhibitors, namely ixazomib and carfilzomib, are under evaluation in AL amyloidosis, but data are premature and their use cannot be recommended outside a clinical trial.

Immunomodulatory-Based Regimens: Thalidomide. Thalidomide was the first immunomodulatory drug (IMiD) to be investigated in AL amyloidosis, and can pro-

Acta Haematol 2016;135:172-190 
duce modest clinical benefit as a single agent [123], but is associated with significant toxicity and is poorly tolerated. In a phase II trial, at a starting dose of $200 \mathrm{mg} /$ day, the drug was not well tolerated in all patients [124]. Therefore, current recommendation suggests an initial dose of no more than $50 \mathrm{mg} /$ day, which can be increased if response is suboptimal and the drug is tolerated.

In combination with dexamethasone, thalidomide has been shown to produce an HR in $48 \%$ of patients in a relapsed setting, and $26 \%$ also achieved an OR. However, toxicity was high, as $65 \%$ experienced grade 3-4 AEs with a median thalidomide dose of $300 \mathrm{mg} /$ day [125]. Thalidomide in combination with cyclophosphamide and dexamethasone (CTD) yielded a 74\% HR in a mixed population of newly diagnosed and advanced-stage patients. Toxicity was high, with more than half of the patients experiencing grade 2 or greater AEs [126]. In a recent matched comparison of CTD with CyBorD in newly diagnosed patients, a similar HR ( 80 vs. $71 \%$, respectively) and 1-year overall survival ( 67 vs. $65 \%$, respectively) was found between the two regimens. However, CyBorD was associated with a higher CR rate ( $24 \mathrm{vs.} 40 \%$, respectively) and longer median PFS (14 vs. 28 months, respectively) [127], favoring its use over CTD.

Immunomodulatory-Based Regimens: Lenalidomide. As a single agent, lenalidomide activity is limited, but increased when dexamethasone was added [128]. Like thalidomide, lenalidomide is less well tolerated in AL amyloidosis than MM, and the recommended initial dose is not to exceed $15 \mathrm{mg} /$ day [129]. Three trials have evaluated lenalidomide in combination with melphalan and dexamethasone, one in a newly diagnosed cohort [130] and the other two studies with both newly diagnosed and relapsed patients [131, 132]. An HR was seen in 50-58\% of patients in the trials, but the CR rate was highly variable, ranging from $42 \%$ in the de novo setting to $7-8 \%$ in the mixed-population trials. The reason for the lower CR rates in these two trials may stem from the lower lenalidomide dose used ( $10 \mathrm{mg}$ /day) compared to $15 \mathrm{mg} /$ day in the former trial, and a higher proportion of cardiac patients ( $92 \%$ in one trial). OR varied between these trials, from 7 to $50 \%$, correlating directly with the complete hematologic response rate. The most common AEs were cytopenia, nausea, diarrhea/constipation, fatigue, skin rash and infection. Another recently explored combination regimen consisted of lenalidomide, cyclophosphamide and dexamethasone. In the newly diagnosed setting, this regimen produced an HR in $46 \%$ of patients, with a CR of $18 \%$ [111]. An OR was seen in 46\%. This trial had a high proportion of cardiac patients and has demonstrated that patients with advanced cardiac stage were less likely to respond, similar to results seen with other conventional chemotherapy regimens. Three subsequent trials evaluated this combination regimen in a mixed population of patients [133-135], revealing an HR in 55-62\% (CR $5-11 \%)$ and OR in $19-29 \%$ of patients.

Two specific concerns regarding lenalidomide toxicity should be acknowledged. The first is the occurrence of lenalidomide-related renal deterioration in a high proportion of patients, $66 \%$ in one report, of which $10 \%$ necessitated dialysis [136]. Although more likely in patients with underlying renal amyloidosis, functional decline can occur even in its absence. Renal recovery was seen in only $44 \%$ of patients. The second concern is the rise of NTproBNP/BNP in a substantial portion of lenalidomidetreated patients $[137,138]$. It is unclear if this indicates cardiac toxicity, fluid retention by lenalidomide or impaired renal clearance of this biomarker. This rise was reported to be asymptomatic and was not predictive of shortened survival.

Pomalidomide, a third-generation IMiD, has been explored in combination with weekly dexamethasone in a phase II trial [139]. Thirty-three patients with at least one prior regimen were enrolled. HR was documented in $48 \%$ of patients and CR in 3\%. Prior IMiDs exposure did not affect the response rate. OR occurred in $15 \%$ of patients. A dose reduction was required in half of the patients, mostly due to neutropenia. As with lenalidomide, a rise in NT-proBNP occurred in most of the patients, including patients with hematological and cardiac responses.

\section{Supportive Care}

Cardiac Support Care

Cardiac amyloidosis is common in $\mathrm{AL}$ amyloidosis, bears a high symptom burden and carries the poorest outcome among all organs. Therefore, it deserves a special focus on supportive care requirements, although most recommendations are derived from low-quality data. Although important to know the 'to do's' in cardiac management, knowing the 'do not do's' for these patients is as important.

Sudden cardiac death (SCD) accounts for approximately one third of early deaths in AL amyloidosis [140]. Although fatal ventricular arrhythmias are encountered, most SCDs are attributed to electromechanical dissociation (EMD; also referred to as pulseless electrical activity), which is not amenable to cardioversion-defibrillation [141]. In one trial assessing 19 patients who were deemed high risk for SCD, only 2 patients were successfully treat- 
ed with electrical shock for sustained ventricular tachyarrhythmia, and most patients died due to EMD [142]. Another report suggested a benefit of an implantable cardioverter defibrillator (ICD) in a subset of patients with a history of sustained and/or nonsustained ventricular tachycardia [143], but lacked a comparator arm. Our experience suggests that despite appropriate shock delivery, lack of a survival benefit for ICD implantation indicates a difficulty in appropriate patient selection [144]. Identification of indications for ICD installation await collaborative trials.

Heart failure management is challenging. Most medication used for heart failure management are not well tolerated by cardiac amyloidosis patients. Angiotensinconverting enzyme inhibitors and angiotensin receptor blockers often lead to profound hypotension, even in modest doses, and their use should be discouraged [145]. Beta-blockers may aggravate hypotension due to the fixed stroke volume and need for a higher heart rate to maintain cardiac output. Similarly, calcium channel blockers are relatively contraindicated as they can worsen heart failure due to the negative inotropic effect [146]. Therefore, loop diuretics and aldosterone antagonists remain the mainstay of treatment, requiring frequent monitoring for changes in creatinine and electrolytes. For tachyarrhythmia rate control, digoxin has been shown to bind amyloid fibrils [147], increasing the risk of digoxin toxicity, and its use is infrequent. Amiodarone may be considered, but has not been proven as beneficial or safe. Betablockers may be used cautiously for this purpose [148]. Left ventricular assist device has emerged as a new treatment modality for refractory heart failure. However, its use in cardiac amyloidosis has been primarily reserved for non-AL amyloidosis [149], reflecting strict patient selection as a result of serious AEs associated with the device [150]. Its use should be restricted to patients with isolated cardiac amyloidosis.

For hypotension management, due to autonomic dysfunction, it is advisable to perform simple measures such as avoiding dehydration and excessive use of diuretics, gradual movement with postural change and using elastic stockings, preferably those which extend to the waist. If these measures are unsatisfactory, pharmacologic intervention should be considered. The most common drugs in use are midodrine, a selective $\alpha 1$-adrenegic agonist, at a dose of 2.5-10 mg 2-4 times per day, and fluorohydrocortisone, a mineralocorticoid, at a dose of $0.05-0.3 \mathrm{mg}$ daily [151]. It is recommended to start at a lower dose level and increase the dose if tolerated and the desired effect is not achieved.

Immunoglobulin AL Amyloidosis Review

\section{Nutrition}

Patients with AL amyloidosis often present with malnourishment as a result of multiple factors. These factors include insufficient energy intake, systemic catabolic factors, organ involvement interfering with absorption (e.g. macroglossia, GIT involvement, autonomic dysfunction causing GIT dysmotility, etc.) and/or nutrient loss (significant proteinuria). Is has been demonstrated that poor nutritional status is associated with the number of involved organs, advanced Mayo stage as well as reduced quality of life and poorer overall survival [152-154].

In an Italian single-center open-label RCT [85], AL amyloidosis patients were randomly assigned to either regular nutritional consulting by a dietitian or to nondietitian-led nutritional counseling. Patients in the interventional arm had better caloric intake and better survival compared with conventional nutritional counselling, highlighting the importance of simple measures in preserving adequate intake.

\section{Novel Therapies for AL Amyloidosis:}

\section{Amyloid Deposit-Targeted Therapies}

SAP Antibodies

SAP is a glycoprotein which is part of all amyloid deposits, regardless of the misfolding protein origin. SAP contributes to fibril stabilization and proteolytic resistance. In 2010, a report by Bodin et al. [155] demonstrated a phagocytic-mediated removal of amyloid visceral deposition in mice treated with anti-human SAP monoclonal antibodies. As SAP also normally circulates in the bloodstream, prior treatment with a drug named CPHPC, which removes SAP from the circulation, allows better targeting of the tissue deposits by anti-SAP antibodies. A phase I trial in which a 3-day CPHPC treatment was followed by a single anti-SAP infusion showed a reduction in amyloid deposits, mainly hepatic, in those who received a higher antibody dose [156]. This trial enrolled 15 patients, 8 of whom had AL amyloidosis. Cardiac amyloidosis patients were excluded from participation.

Another monoclonal antibody, NEOD001, targets misfolded LCs at the amyloid deposits and render them susceptible to phagocytosis. Interim results of a phase I trial have been reported [157]. Twenty-seven AL amyloidosis patients, including cardiac patients, received monthly NEOD001 infusion for a median of 12 treatments. Treatment was safe with minimal toxicity. Cardiac and renal responses occurred in 57 and $60 \%$ of evaluable patients, respectively, with deeper responses associated with longer treatment periods. The currently recruiting VITAL trial, a phase 3 global trial, will evaluate

Acta Haematol 2016;135:172-190 
the efficacy and safety of NEOD001 plus standard care versus placebo and standard care in untreated AL amyloidosis with cardiac or renal involvement [158].

\section{Doxycycline}

Following promising results in a TTR amyloidosis model, doxycycline has also been shown to inhibit amyloid formation in a transgenic AL amyloidosis mouse model [159]. Its mode of action is thought to involve fibril disruption and disaggregation. A case-control study reported a significant reduction in early mortality when doxycycline was added to a bortezomib-based triplet regimen without an impact on HR [160]. Currently, two phase II trials for the evaluation of doxycycline in AL amyloidosis are accruing in the USA [161, 162].

\section{Green Tea}

This rather unexpected observation was first published as a 'Letter to the editor' in Blood in 2007 by a hematologist suffering from AL amyloidosis, and described improved cardiac parameters and quality of life with the consumption of green tea in large volumes [163]. This was followed by a case-control study in which 11 patients treated predominantly with MDex who also consumed green tea demonstrated functional class improvements as well as a decrease in cardiac mass compared to 22 historical controls [164]. The beneficial effect of green tea is ascribed to epigallocatechin gallate, a naturally derived phenol enriched in green tea, which is able to interfere with the aggregation of the amyloidogenic proteins in vitro [165]. In TTR cardiac amyloidosis there are promising results reported with the use of green tea $[166,167]$. A single-center randomized trial is currently underway to assess the significance of green tea extracts in the management of AL amyloidosis [168]. However, all green tea data comes from a single institution, and until more solid data arrive, the use of green tea should remain investigational at this time. Epigallocatechin gallate was reported to antagonize bortezomib action in vitro [169].

\section{Conclusions}

AL amyloidosis represents a challenging disease in recognition, diagnosis and treatment. Diagnosis is often delayed, and this translates into a higher disease burden and poorer survival, especially when there is cardiac involvement. Diagnosis is based on pathological evaluation and may require several diagnostic specimens to reach a diagnosis. It is important to type the amyloid, as treatment is type specific. Along with the rise of new treatments for $\mathrm{MM}$, novel agents have been incorporated into AL amyloidosis management, but their ultimate impact is still not determined. ASCT remains the best treatment option when strict eligibility criteria are met. Patients with advanced cardiac amyloidosis still lack good treatment options, reflecting a major unmet need. Currently, investigational amyloid-targeted therapies may add important new tools to the treatment arsenal for AL amyloidosis.

\section{Disclosure Statement}

E.M. and F.K.B. have no conflicts of interest to report. A.D. received research funds from Pfizer, Celgene, Janssen, GSK, Alnylam and Takeda. M.A.G. received honoraria from Celgene, Novartis, ISIS, GSK and Sandoz.

\section{References}

1 Kyle RA: Amyloidosis: a brief history. Amyloid 2011;18(suppl 1):6-7.

2 Kyle RA: Amyloidosis: a convoluted story. $\mathrm{Br}$ J Haematol 2001;114;529-538.

3 Sipe JD, Benson MD, Buxbaum JN, Ikeda S, Merlini G, Saraiva MJM, Westermark P: Nomenclature 2014: amyloid fibril proteins and clinical classification of the amyloidosis. Amyloid 2014;21:221-224.

4 Merlini G, Seldin DC, Gertz MA: Amyloidosis: pathogenesis and new therapeutic options. J Clin Oncol 2011;29:1924-1933.

5 Kyle RA, Linos A, Beard CM, Linke RP, Gertz MA, O'Fallon WM, Kurland LT: Incidence and natural history of primary systemic amyloidosis in Olmsted County, Minnesota, 1950 through 1989. Blood 1992;79:1817-1822.
6 Hemminki K, Li X, Försti A, Sundquist J, Sundquist K: Incidence and survival in nonhereditary amyloidosis in Sweden. BMC Public Health 2012;12:974.

7 Pinney JH, Smith CJ, Taube JB, Lachmann HJ, Venner CP, Gibbs SDJ, Dungu J, Banypersad SM, Wechalekar AD, Whelan CJ, Hawkins PN, Gillmore JD: Systemic amyloidosis in England: an epidemiological study. $\mathrm{Br}$ J Haematol 2013;161:525-532.

8 Kourelis TV, Kumar SK, Gertz MA, Lacy MQ, Buadi FK, Hayman SR, Zeldenrust S, Leung N, Kyle RA, Russell S, Dingli D, Lust JA, Lin Y, Kapoor P, Rajkumar SV, McCurdy A, Dispenzieri A: Coexistent multiple myeloma or increased bone marrow plasma cells define equally high-risk populations in patients with immunoglobulin light chain amyloidosis. Clin Oncol 2013;31:4319-4324.

9 Kourelis TV, Kumar SK, Go RS, Kapoor P, Kyle RA, Buadi FK, Gertz MA, Lacy MQ, Hayman SR, Leung N, Dingli D, Lust JA, Lin Y, Zeldenrust SR, Rajkumar SV, Dispenzieri A: Immunoglobulin light chain amyloidosis is diagnosed late in patients with preexisting plasma cell dyscrasias. Am J Hematol 2014;89:1051-1054.

10 Weiss BM, Abadie J, Verma P, Howard RS, Kuehl WM: A monoclonal gammopathy precedes multiple myeloma in most patients. Blood 2009; 113:5418-5422.

11 Villar-Piqué A, Espargaró A, Ventura S, Sabate R: Screening for amyloid aggregation: insilico, in-vitro and in-vivo detection. Curr Protein Pept Sci 2014;15:477-489. 
12 Ahmed AB, Kajava AV: Breaking the amyloidogenicity code: methods to predict amyloids from amino acid sequence. FEBS Lett 2013;587:1089-1095.

13 Merlini G, Bellotti V: Molecular mechanisms of amyloidosis. N Engl J Med 2003;349:583-596.

14 Bellotti V, Nuvolone M, Giorgetti S, Obici L, Palladini G, Russo P, Lavatelli F, Perfetti V, Merlini G: The workings of the amyloid diseases. Ann Med 2007;39:200-207.

15 Chiti F, Dobson CM: Protein misfolding, functional amyloid, and human disease. Annu Rev Biochem 2006;75:333-366.

16 McWilliams-Koeppen HP, Foster JS, Hackenbrack N, Ramirez-Alvarado M, Donohoe D, Williams A, Macy S, Wooliver C, Wortham D, Morrell-Falvey J, Foster CM, Kennel SJ, Wall JS: Light chain amyloid fibrils cause metabolic dysfunction in human cardiomyocytes. PloS One 2015;10:e0137716.

17 Shi J, Guan J, Jiang B, Brenner DA, Del Monte F, Ward JE, Connors LH, Sawyer DB, Semigran MJ, Macgillivray TE, Seldin DC, Falk R, Liao R: Amyloidogenic light chains induce cardiomyocyte contractile dysfunction and apoptosis via a non-canonical p38a MAPK pathway. Proc Natl Acad Sci USA 2010;107: 4188-4193.

18 Sikkink LA, Ramirez-Alvarado M: Cytotoxicity of amyloidogenic immunoglobulin light chains in cell culture. Cell Death Dis 2010; 1:e98.

19 Zeier M, Perz J, Linke RP, Donini U, Waldherr R, Andrassy K, Ho AD, Goldschmidt H: No regression of renal AL amyloid in monoclonal gammopathy after successful autologous blood stem cell transplantation and significant clinical improvement. Nephrol Dial Transplant 2003;18:2644-2647.

20 Okuyama H, Yamaya H, Fukusima T, Yokoyama $\mathrm{H}$ : A patient with persistent renal $\mathrm{AL}$ amyloid deposition after clinical remission by HDM/SCT therapy. Clin Nephrol 2013;79: 233-236.

21 Gertz MA, Kyle RA, Griffing WL, Hunder GG: Jaw claudication in primary systemic amyloidosis. Medicine (Baltimore) 1986;65: 173-179.

22 Matsuda M, Katoh N, Ikeda S: Clinical manifestations at diagnosis in Japanese patients with systemic AL amyloidosis: a retrospective study of 202 cases with a special attention to uncommon symptoms. Intern Med 2014;53: 403-412.

23 Gertz MA, Kyle RA: Myopathy in primary systemic amyloidosis. J Neurol Neurosurg Psychiatry 1996;60:655-660.

24 Jardinet D, Westhovens R, Peeters J: Sicca syndrome as an initial symptom of amyloidosis. Clin Rheumatol 1998;17:546-548.

25 Lutz ME, Pittelkow MR: Progressive generalized alopecia due to systemic amyloidosis. J Am Acad Dermatol 2002;46:434-436.
26 Comenzo RL, Wally J, Kica G, Murray J, Ericsson T, Skinner M, Zhang Y: Clonal immunoglobulin light chain variable region germline gene use in AL amyloidosis: association with dominant amyloid-related organ involvement and survival after stem cell transplantation. Br J Haematol 1999;106:744-751.

27 Abraham RS, Geyer SM, Price-Troska TL, Allmer C, Kyle RA, Gertz MA, Fonseca R: Immunoglobulin light chain variable $(\mathrm{V})$ region genes influence clinical presentation and outcome in light chain-associated amyloidosis (AL). Blood 2003;101:3801-3808.

28 Comenzo RL, Zhang Y, Martinez C, Osman K, Herrera GA: The tropism of organ involvement in primary systemic amyloidosis: contributions of Ig $\mathrm{V}_{L}$ germ line gene use and clonal plasma cell burden. Blood 2001;98: 714-720.

29 Bellavia D, Abraham RS, Pellikka PA, Dispenzieri A, Burnett JC, Al-Zahrani GB, Green TD, Manske MK, Gertz MA, Miller FA, Abraham TP: Utility of Doppler myocardial imaging, cardiac biomarkers, and clonal immunoglobulin genes to assess left ventricular performance and stratify risk following peripheral blood stem cell transplantation in patients with systemic light chain amyloidosis (AL). J Am Soc Echocardiogr 2011;24:444-454.

30 Diomede L, Rognoni P, Lavatelli F, Romeo M, del Favero E, Cantù L, Ghibaudi E, di Fonzo A, Corbelli A, Fiordaliso F, Palladini G, Valentini V, Perfetti V, Salmona M, Merlini G: A Caenorhabditis elegans-based assay recognizes immunoglobulin light chains causing heart amyloidosis. Blood 2014;123:3543-3552.

31 Dispenzieri A, Gertz MA, Buadi F: What do I need to know about immunoglobulin light chain (AL) amyloidosis? Blood Rev 2012;26: 137-154.

32 Merlini G, Stone MJ: Dangerous small B-cell clones. Blood 2006;108;2520-2530.

33 Dispenzieri A, Kyle R, Merlini G, Miguel JS, Ludwig H, Hajek R, Palumbo A, Jagannath S, Blade S, Lonial S, Dimopoulos M, Comenzo R, Einsele H, Barlogie B, Anderson K, Gertz M, Harousseau JL, Attal M, Tosi P, Sonneveld P, Boccadoro M, Morgan G, Richardson P, Sezer O, Mateos MV, Cavo M, Joshua D, Turesson I, Chen W, Shimizu K, Powles R, Rajkumar SV, Durie BGM; International Myeloma Working Group: International Myeloma Working Group guidelines for serum-free light chain analysis in multiple myeloma and related disorders. Leukemia 2009;23:215-224.

34 Katzmann JA: Screening panels for monoclonal gammopathies: time to change. Clin Biochem Rev Aust Assoc Clin Biochem 2009;30: 105-111.

35 Gertz MA, Lacy MQ, Dispenzieri A, Hayman SR, Kumar SK, Dingli D, Ansell SM, Gastineau DA, Inwards DJ, Johnston PB, Litzow MR, Micallef INM, Porrata LF, Leung N, Hogan WJ, Buadi FK: Autologous stem cell transplant for immunoglobulin light chain amyloidosis: a status report. Leuk Lymphoma 2010;51:2181-2187.
36 Miyazaki K, Kawai S, Suzuki K: Abdominal subcutaneous fat pad aspiration and bone marrow examination for the diagnosis of $\mathrm{AL}$ amyloidosis: the reliability of immunohistochemistry. Int J Hematol 2015;102:289-295.

37 Shidham VB, Hunt B, Jardeh SS, Barboi AC, Devata S, Hari P: Performing and processing FNA of anterior fat pad for amyloid. J Vis Exp 2010;44:1747.

38 van Gameren II, Hazenberg BPC, Bijzet J, van Rijswijk MH: Diagnostic accuracy of subcutaneous abdominal fat tissue aspiration for detecting systemic amyloidosis and its utility in clinical practice. Arthritis Rheum 2006;54: 2015-2021.

39 Kyle RA, Gertz MA: Primary systemic amyloidosis: clinical and laboratory features in 474 cases. Semin Hematol 1995;32:45-59.

40 Foli A, Palladini G, Caporali R, Verga L, Morbini P, Obici L, Russo P, Sarais G, Donadei S, Montecucco C, Merlini G: The role of minor salivary gland biopsy in the diagnosis of systemic amyloidosis: results of a prospective study in 62 patients. Amyloid 2011; 18(suppl 1):80-82.

41 Vrana JA, Gamez JD, Madden BJ, Theis JD, Bergen HR, Dogan A: Classification of amyloidosis by laser microdissection and mass spectrometry-based proteomic analysis in clinical biopsy specimens. Blood 2009;114: 4957-4959.

42 Leung N, Nasr SH, Sethi S: How I treat amyloidosis: the importance of accurate diagnosis and amyloid typing. Blood 2012;120:32063213.

43 Kyle RA, San-Miguel JF, Mateos M-V, Rajkumar SV: Monoclonal gammopathy of undetermined significance and smoldering multiple myeloma. Hematol Oncol Clin North Am 2014;28:775-790.

44 Lachmann HJ, Booth DR, Booth SE, Bybee A, Gilbertson JA, Gillmore JD, Pepys MB, Hawkins PN: Misdiagnosis of hereditary amyloidosis as AL (primary) amyloidosis. N Engl J Med 2002;346:1786-1791.

45 Linke RP: On typing amyloidosis using immunohistochemistry: detailed illustrations, review and a note on mass spectrometry. Prog Histochem Cytochem 2012;47:61-132.

46 Schönland SO, Hegenbart U, Bochtler T, Mangatter A, Hansberg M, Ho AD, Lohse P, Röcken C: Immunohistochemistry in the classification of systemic forms of amyloidosis: a systematic investigation of 117 patients. Blood 2012;119:488-493.

47 Arbustini E, Verga L, Concardi M, Palladini G, Obici L, Merlini G: Electron and immunoelectron microscopy of abdominal fat identifies and characterizes amyloid fibrils in suspected cardiac amyloidosis. Amyloid 2002;9: 108-114.

48 Kyle RA, Bayrd ED: Amyloidosis: review of 236 cases. Medicine (Baltimore) 1975;54: 271-299. 
49 Bhat A, Selmi C, Naguwa SM, Cheema GS, Gershwin ME: Currents concepts on the immunopathology of amyloidosis. Clin Rev Allergy Immunol 2010;38:97-106.

50 Westermark P: Localized AL amyloidosis: a suicidal neoplasm? Ups J Med Sci 2012;117: 244-250.

51 Paccalin M, Hachulla E, Cazalet C, Tricot L, Carreiro M, Rubi M, Grateau G, Roblot P: Localized amyloidosis: a survey of 35 French cases. Amyloid 2005;12:239-245.

52 Palladini G, Sachchithanantham S, Milani P, Gillmore J, Foli A, Lachmann H, Basset M, Hawkins P, Merlini G, Wechalekar AD: A European collaborative study of cyclophosphamide, bortezomib, and dexamethasone in upfront treatment of systemic AL amyloidosis. Blood 2015;126:612-615.

53 Skinner M, Sanchorawala V, Seldin DC, Dember LM, Falk RH, Berk JL, Anderson JJ, O'Hara C, Finn KT, Libbey CA, Wiesman J, Quillen K, Swan N, Wright DG: High-dose melphalan and autologous stem-cell transplantation in patients with AL amyloidosis: an 8-year study. Ann Intern Med 2004;140: 85-93.

54 Palladini G, Barassi A, Klersy C, Pacciolla R, Milani P, Sarais G, Perlini S, Albertini R, Russo P, Foli A, Bragotti LZ, Obici L, Moratti R, Melzi d'Eril GV, Merlini G: The combination of high-sensitivity cardiac troponin $\mathrm{T}$ (hs$c \operatorname{Tn} \mathrm{T})$ at presentation and changes in $\mathrm{N}$-terminal natriuretic peptide type B (NT-proBNP) after chemotherapy best predicts survival in AL amyloidosis. Blood 2010;116: 3426-3430.

55 Palladini G, Campana C, Klersy C, Balduini A, Vadacca G, Perfetti V, Perlini S, Obici L, Ascari E, d' Eril GM, Moratti R, Merlini G: Serum $\mathrm{N}$-terminal pro-brain natriuretic peptide is a sensitive marker of myocardial dysfunction in AL amyloidosis. Circulation 2003; 107:2440-2445.

56 Sharma PP, Payvar S, Litovsky SH: Histomorphometric analysis of intramyocardial vessels in primary and senile amyloidosis: epicardium versus endocardium. Cardiovasc Pathol 2008; 17;65-71.

57 Daubert JP, Gaede J, Cohen HJ: A fatal case of constrictive pericarditis due to a marked, selective pericardial accumulation of amyloid. Am J Med 1993;94:335-340.

58 Wittich CM, Neben-Wittich MA, Mueller PS, Gertz MA, Edwards WD: Deposition of amyloid proteins in the epicardial coronary arteries of 58 patients with primary systemic amyloidosis. Cardiovasc Pathol 2007;16:75-78.

59 Gertz MA, Comenzo R, Falk RH, Fermand JP, Hazenberg BP, Hawkins PN, Merlini G, Moreau P, Ronco P, Sanchorawala V, Sezer O, Solomon A, Grateau G: Definition of organ involvement and treatment response in immunoglobulin light chain amyloidosis (AL): a consensus opinion from the 10th International Symposium on Amyloid and Amyloidosis, Tours, France, 18-22 April 2004. Am J Hematol 2005;79:319-328.
60 Suresh R, Grogan M, Maleszewski JJ, Pellikka PA, Hanna M, Dispenzieri A, Pereira NL: Advanced cardiac amyloidosis associated with normal interventricular septal thickness: an uncommon presentation of infiltrative cardiomyopathy. J Am Soc Echocardiogr 2014; 27:440-447.

61 Lee GY, Kim K, Choi J-O, Kim SJ, Kim J-S, Choe YH, Grogan MA, Jeon E-S: Cardiac amyloidosis without increased left ventricular wall thickness. Mayo Clin Proc 2014;89:781-789.

62 Bellavia D, Pellikka PA, Al-Zahrani GB, Abraham TP, Dispenzieri A, Miyazaki C, Lacy M, Scott CG, Oh JK, Miller FA: Independent predictors of survival in primary systemic (AL) amyloidosis, including cardiac biomarkers and left ventricular strain imaging: an observational cohort study. J Am Soc Echocardiogr 2010;23:643-652.

63 Hashimura H, Ishibashi-Ueda H, Yonemoto Y, Ohta-Ogo K, Matsuyama T-A, Ikeda Y, Morita Y, Yamada N, Yasui H, Naito H: Late gadolinium enhancement in cardiac amyloidosis: attributable both to interstitial amyloid deposition and subendocardial fibrosis caused by ischemia. Heart Vessels 2015, Epub ahead of print.

64 Syed IS, Glockner JF, Feng D, Araoz PA, Martinez MW, Edwards WD, Gertz MA, Dispenzieri A, Oh JK, Bellavia D, Tajik AJ, Grogan M: Role of cardiac magnetic resonance imaging in the detection of cardiac amyloidosis. JACC Cardiovasc Imaging 2010;3:155-164.

65 Fontana M, Pica S, Reant P, Abdel-Gadir A, Treibel TA, Banypersad SM, Maestrini V, Barcella W, Rosmini S, Bulluck H, Sayed RH, Patel K, Mahmood S, Bucciarelli-Ducci C, Whelan CJ, Herrey AS, Lachmann HJ, Wechalekar AD, Manisty CH, Schelbert EB, Kellman P, Gillmore JD, Hawkins PN, Moon JC: Prognostic value of late gadolinium enhancement cardiovascular magnetic resonance in cardiac amyloidosis. Circulation 2015;132:1570-1579.

66 Talamo G, Mir Muhammad A, Pandey MK, Zhu J, Creer MH, Malysz J: Estimation of daily proteinuria in patients with amyloidosis by using the protein-to-creatinine ratio in random urine samples. Rare Tumors 2015;7: 5686.

67 Bergesio F, Ciciani AM, Santostefano M, Brugnano R, Manganaro M, Palladini G, Di Palma AM, Gallo M, Tosi PL, Salvadori M; Immunopathology Group, Italian Society of Nephrology: Renal involvement in systemic amyloidosis - an Italian retrospective study on epidemiological and clinical data at diagnosis. Nephrol Dial Transplant 2007;22: 1608-1618.

68 Eirin A, Irazabal MV, Gertz MA, Dispenzieri A, Lacy MQ, Kumar S, Sethi S, Nasr SH, Cornell LD, Fidler ME, Fervenza FC, Leung N: Clinical features of patients with immunoglobulin light chain amyloidosis (AL) with vascular-limited deposition in the kidney. Nephrol Dial Transplant 2012;27:10971101.
69 Dingli D, Tan TS, Kumar SK, Buadi FK, Dispenzieri A, Hayman SR, Lacy MQ, Gastineau DA, Hogan WJ, Gertz MA: Stem cell transplantation in patients with autonomic neuropathy due to primary (AL) amyloidosis. Neurology 2010;74:913-918.

70 Sachchithanantham S, Wechalekar AD: Imaging in systemic amyloidosis. Br Med Bull 2013;107:41-56.

71 Kyle RA, Gertz MA, Greipp PR, Witzig TE, Lust JA, Lacy MQ, Therneau TM: A trial of three regimens for primary amyloidosis: colchicine alone, melphalan and prednisone, and melphalan, prednisone, and colchicine. $\mathrm{N}$ Engl J Med 1997;336:1202-1207.

72 Castaño A, Drachman BM, Judge D, Maurer MS: Natural history and therapy of TTR-cardiac amyloidosis: emerging disease-modifying therapies from organ transplantation to stabilizer and silencer drugs. Heart Fail Rev 2015;20:163-178.

73 Ng B, Connors LH, Davidoff R, Skinner M, Falk RH: Senile systemic amyloidosis presenting with heart failure: a comparison with light chain-associated amyloidosis. Arch Intern Med 2005;165:1425-1429.

74 Dispenzieri A, Gertz MA, Kyle RA, Lacy MQ, Burritt MF, Therneau TM, Greipp PR, Witzig TE, Lust JA, Rajkumar SV, Fonseca R, Zeldenrust SR, McGregor CGA, Jaffe AS: Serum cardiac troponins and $\mathrm{N}$-terminal pro-brain natriuretic peptide: a staging system for primary systemic amyloidosis. J Clin Oncol 2004;22: 3751-3757.

75 Kumar S, Dispenzieri A, Lacy MQ, Hayman SR, Buadi FK, Colby C, Laumann K, Zeldenrust SR, Leung N, Dingli D, Greipp PR, Lust JA, Russell SJ, Kyle RA, Rajkumar SV, Gertz MA: Revised prognostic staging system for light chain amyloidosis incorporating cardiac biomarkers and serum free light chain measurements. J Clin Oncol 2012;30:989-995.

76 Palladini G, Foli A, Milani P, Russo P, Albertini R, Lavatelli F, Obici L, Perlini S, Moratti R, Merlini G: Best use of cardiac biomarkers in patients with AL amyloidosis and renal failure. Am J Hematol 2012;87:465-471.

77 Dispenzieri A, Gertz MA, Kumar SK, Lacy MQ, Kyle RA, Saenger AK, Grogan M, Zeldenrust SR, Hayman SR, Buadi F, Greipp PR, Leung N, Russell SR, Dingli D, Lust JA, Rajkumar SV, Jaffe AS: High sensitivity cardiac troponin $\mathrm{T}$ in patients with immunoglobulin light chain amyloidosis. Heart $\mathrm{Br}$ Card Soc 2014;100:383-388.

78 Gertz MA, Kyle RA, Greipp PR: Response rates and survival in primary systemic amyloidosis. Blood 1991;77:257-262.

79 Cordes S, Dispenzieri A, Lacy MQ, Hayman SR, Buadi FK, Dingli D, Kumar SK, Hogan WJ, Gertz MA: Ten-year survival after autologous stem cell transplantation for immunoglobulin light chain amyloidosis. Cancer 2012;118:6105-6109. 
80 Warsame R, Kumar SK, Gertz MA, Lacy MQ, Buadi FK, Hayman SR, Leung N, Dingli D, Lust JA, Ketterling RP, Lin Y, Russell S, Hwa L, Kapoor P, Go RS, Zeldenrust SR, Kyle RA, Rajkumar SV, Dispenzieri A: Abnormal FISH in patients with immunoglobulin light chain amyloidosis is a risk factor for cardiac involvement and for death. Blood Cancer J 2015;5:e310.

81 Wechalekar AD, Schonland SO, Kastritis E, Gillmore JD, Dimopoulos MA, Lane T, Foli A, Foard D, Milani P, Rannigan L, Hegenbart U, Hawkins PN, Merlini G, Palladini G: A European collaborative study of treatment outcomes in 346 patients with cardiac stage III AL amyloidosis. Blood 2013;121:3420-3427.

82 Mollee PN, Wechalekar AD, Pereira DL, Franke N, Reece D, Chen C, Stewart AK: Autologous stem cell transplantation in primary systemic amyloidosis: the impact of selection criteria on outcome. Bone Marrow Transplant 2004;33:271-277.

83 Kumar S, Dispenzieri A, Lacy MQ, Hayman SR, Leung N, Zeldenrust SR, Buadi FK, Kyle RA, Rajkumar SV, Gertz MA: Serum uric acid: novel prognostic factor in primary systemic amyloidosis. Mayo Clin Proc 2008;83:297-303.

84 Kumar SK, Gertz MA, Lacy MQ, Dingli D, Hayman SR, Buadi FK, Short-Detweiler K, Zeldenrust SR, Leung N, Greipp PR, Lust JA, Russell SJ, Kyle RA, Rajkumar SV, Dispenzieri A: Recent improvements in survival in primary systemic amyloidosis and the importance of an early mortality risk score. Mayo Clin Proc 2011;86:12-18.

85 Caccialanza R, Palladini G, Klersy C, Cereda E, Bonardi C, Cameletti B, Quarleri L, Montagna E, Foli A, Milani P, Lavatelli F, Marena C, Merlini G: Malnutrition at diagnosis predicts mortality in patients with systemic immunoglobulin light-chain amyloidosis independently of cardiac stage and response to treatment. JPEN J Parenter Enteral Nutr 2014; 38:891-894.

86 Kristen AV, Rosenberg M, Lindenmaier D, Merkle C, Steen H, Andre F, Schönland SO, Schnabel PA, Schuster T, Röcken C, Giannitsis E, Katus HA, Frey N: Osteopontin: a novel predictor of survival in patients with systemic light-chain amyloidosis. Amyloid 2014;21: 202-210.

87 Dispenzieri A, Gertz MA, Saenger A, Kumar SK, Lacy MQ, Buadi FK, Dingli D, Leung N, Zeldenrust S, Hayman SR, Kapoor P, Grogan M, Hwa L, Russell SJ, Go RS, Rajkumar SV, Kyle RA, Jaffe A: Soluble suppression of tumorigenicity 2 (sST2), but not galactin- 3 , adds to prognostication in patients with systemic AL amyloidosis independent of NTproBNP and troponin T. Am J Hematol 2015; 90:524-528.

88 Kristen AV, Rinn J, Hegenbart U, Lindenmaier D, Merkle C, Röcken C, Hardt S, Giannitsis E, Katus HA: Improvement of risk assessment in systemic light-chain amyloidosis using human placental growth factor. Clin Res Cardiol 2015;104:250-257.
89 Palladini G, Dispenzieri A, Gertz MA, Kumar S, Wechalekar A, Hawkins PN, Schönland S, Hegenbart U, Comenzo R, Kastritis E, Dimopoulos MA, Jaccard A, Klersy C, Merlini G: New criteria for response to treatment in immunoglobulin light chain amyloidosis based on free light chain measurement and cardiac biomarkers: impact on survival outcomes. J Clin Oncol 2012;30:4541-4549.

90 Dispenzieri A, Lacy MQ, Katzmann JA, Rajkumar SV, Abraham RS, Hayman SR, Kumar SK, Clark R, Kyle RA, Litzow MR, Inwards DJ, Ansell SM, Micallef IM, Porrata LF, Elliott MA, Johnston PB, Greipp PR, Witzig TE, Zeldenrust SR, Russell SJ, Gastineau D, Gertz MA: Absolute values of immunoglobulin free light chains are prognostic in patients with primary systemic amyloidosis undergoing peripheral blood stem cell transplantation. Blood 2006;107:3378-3383.

91 Palladini G, Hegenbart U, Milani P, Kimmich C, Foli A, Ho AD, Vidus Rosin M, Albertini R, Moratti R, Merlini G, Schönland S: A staging system for renal outcome and early markers of renal response to chemotherapy in AL amyloidosis. Blood 2014;124:23252332.

92 Dispenzieri A, Buadi F, Kumar SK, Reeder CB, Sher T, Lacy MQ, Kyle RA, Mikhael JR, Roy V, Leung N, Grogan M, Kapoor P, Lust JA, Dingli D, Go RS, Hwa YL, Hayman SR, Fonseca R, Ailawadhi S, Bergsagel PL, Chanan-Khan A, Rajkumar SV, Russell SJ, Stewart K, Zeldenrust SR, Gertz MA: Treatment of immunoglobulin light chain amyloidosis: Mayo Stratification of Myeloma and Risk-Adapted Therapy (mSMART) Consensus Statement. Mayo Clin Proc 2015;90:1054-1081.

93 Kaufman GP, Dispenzieri A, Gertz MA, Lacy MQ, Buadi FK, Hayman SR, Leung N, Dingli D, Lust JA, Lin Y, Kapoor P, Go RS, Zeldenrust SR, Kyle RA, Rajkumar SV, Kumar SK: Kinetics of organ response and survival following normalization of the serum free light chain ratio in AL amyloidosis. Am J Hematol 2015;90:181-186.

94 Cibeira MT, Sanchorawala V, Seldin DC, Quillen K, Berk JL, Dember LM, Segal A, Ruberg F, Meier-Ewert H, Andrea NT, Sloan JM, Finn KT, Doros G, Blade J, Skinner M: Outcome of AL amyloidosis after high-dose melphalan and autologous stem cell transplantation: long-term results in a series of $421 \mathrm{pa}-$ tients. Blood 2011;118:4346-4352.

95 Gertz MA, Lacy MQ, Dispenzieri A, Kumar SK, Buadi FK, Dingli D, Leung N, Hogan WJ, Hayman SR: Trends in day 100 and 2-year survival after auto-SCT for AL amyloidosis: outcomes before and after 2006. Bone Marrow Transplant 2011;46:970-975.

96 Gertz MA, Lacy MQ, Dispenzieri A, Kumar SK, Dingli D, Leung N, Hogan WJ, Buadi FK, Hayman SR: Refinement in patient selection to reduce treatment-related mortality from autologous stem cell transplantation in amyloidosis. Bone Marrow Transplant 2013;48: 557-561.
97 Jantunen E, Itälä M, Lehtinen T, Kuittinen O, Koivunen E, Leppä S, Juvonen E, Koistinen P, Wiklund T, Nousiainen T, Remes K, Volin L: Early treatment-related mortality in adult autologous stem cell transplant recipients: a nation-wide survey of 1482 transplanted patients. Eur J Haematol 2006;76: 245-250.

98 D'Souza A, Dispenzieri A, Wirk B, Zhang M-J, Huang J, Gertz MA, Kyle RA, Kumar S, Comenzo RL, Peter Gale R, Lazarus HM, Savani $\mathrm{BN}$, Cornell RF, Weiss BM, Vogl DT, Freytes CO, Scott EC, Landau HJ, Moreb JS, Costa LJ, Ramanathan M, Callander NS, Kamble RT, Olsson RF, Ganguly S, Nishihori T, Kindwall-Keller TL, Wood WA, Mark TM, Hari P: Improved outcomes after autologous hematopoietic cell transplantation for light chain amyloidosis: a Center for International Blood and Marrow Transplant Research Study. J Clin Oncol 2015;33:3741-3749.

99 Hegenbart U, Iacobelli S, Hoek J, Rovira M, van Imhoff $\mathrm{G}$, Bandini $\mathrm{G}$, Mellqvist $\mathrm{U}-\mathrm{H}$ Leblond V, Carlson K, Zver S, Blaise D, Alessandrino EP, Garderet L, Kröger N: Center experience and calendar year of transplantation strongly influence short term survival after autologous peripheral blood transplantation in 1,315 patients with light chain amyloidosis: an EBMT analysis. Blood 2013; 122:417-417.

100 Comenzo RL, Vosburgh E, Simms RW, Bergethon P, Sarnacki D, Finn K, Dubrey S, Faller DV, Wright DG, Falk RH, Skinner M: Dose-intensive melphalan with blood stem cell support for the treatment of AL amyloidosis: one-year follow-up in five patients. Blood 1996;88:2801-2806.

101 Dispenzieri A, Seenithamby K, Lacy MQ, Kumar SK, Buadi FK, Hayman SR, Dingli D, Litzow MR, Gastineau DA, Inwards DJ, Micallef IN, Ansell SM, Johnston PB, Porrata LF, Patnaik MM, Hogan WJ, Gertz MA: Patients with immunoglobulin light chain amyloidosis undergoing autologous stem cell transplantation have superior outcomes compared with patients with multiple myeloma: a retrospective review from a tertiary referral center. Bone Marrow Transplant 2013;48:1302-1307.

102 Jaccard A, Moreau P, Leblond V, Leleu X, Benboubker L, Hermine O, Recher C, Asli B, Lioure B, Royer B, Jardin F, Bridoux F, Grosbois B, Jaubert J, Piette J-C, Ronco P, Quet F, Cogne M, J-P, Fermand; Myélome Autogreffe (MAG) and Intergroupe Francophone du Myélome (IFM): High-dose melphalan versus melphalan plus dexamethasone for AL amyloidosis. N Engl J Med 2007; 357:1083-1093.

103 Bashir Q, Langford LA, Parmar S, Champlin RE, Qazilbash MH: Primary systemic amyloid light chain amyloidosis decompensating after filgrastim-induced mobilization and stem-cell collection. J Clin Oncol 2011; 29:e79-e80. 
104 Dhakal B, Strouse C, D'Souza A, Arce-Lara C, Esselman J, Eastwood D, Pasquini M, Saber W, Drobyski W, Rizzo JD, Hari PN, Hamadani M: Plerixafor and abbreviatedcourse granulocyte colony-stimulating factor for mobilizing hematopoietic progenitor cells in light chain amyloidosis. Biol Blood Marrow Transplant 2014;20:19261931.

105 Kaul E, Shah G, Chaulagain C, Comenzo RL: Plerixafor and G-CSF for autologous stem cell mobilization in AL amyloidosis. Bone Marrow Transplant 2014;49:1233.

106 Gertz MA, Lacy MQ, Dispenzieri A, Ansell SM, Elliott MA, Gastineau DA, Inwards DJ, Micallef INM, Porrata LF, Tefferi A, Litzow MR: Risk-adjusted manipulation of melphalan dose before stem cell transplantation in patients with amyloidosis is associated with a lower response rate. Bone Marrow Transplant 2004;34:1025-1031.

107 Sanchorawala V, Wright DG, Seldin DC, Falk RH, Finn KT, Dember LM, Berk JL, Quillen K, Anderson JJ, Comenzo RL, Skinner M: High-dose intravenous melphalan and autologous stem cell transplantation as initial therapy or following two cycles of oral chemotherapy for the treatment of AL amyloidosis: results of a prospective randomized trial. Bone Marrow Transplant 2004;33: 381-388.

108 Huang X, Wang Q, Chen W, Zeng C, Chen Z, Gong D, Zhang H, Liu Z: Induction therapy with bortezomib and dexamethasone followed by autologous stem cell transplantation versus autologous stem cell transplantation alone in the treatment of renal AL amyloidosis: a randomized controlled trial. BMC Med 2014;12:2.

109 Landau H, Hassoun H, Rosenzweig MA, Maurer M, Liu J, Flombaum C, Bello C, Hoover E, Riedel E, Giralt S, Comenzo RL: Bortezomib and dexamethasone consolidation following risk-adapted melphalan and stem cell transplantation for patients with newly diagnosed light-chain amyloidosis. Leukemia 2013;27:823-828.

110 Kastritis E, Roussou M, Gavriatopoulou M, Migkou M, Kalapanida D, Pamboucas C, Kaldara E, Ntalianis A, Psimenou E, Toumanidis ST, Tasidou A, Terpos E, Dimopoulos MA: Long-term outcomes of primary systemic light chain (AL) amyloidosis in patients treated upfront with bortezomib or lenalidomide and the importance of risk adapted strategies. Am J Hematol 2015; 90:E60-E65.

111 Cibeira MT, Oriol A, Lahuerta JJ, Mateos M-V, de la Rubia J, Hernández MT, Granell M, Fernández de Larrea C, San Miguel JF, Bladé J; PETHEMA cooperative study group: A phase II trial of lenalidomide, dexamethasone and cyclophosphamide for newly diagnosed patients with systemic immunoglobulin light chain amyloidosis. $\mathrm{Br} \mathrm{J}$ Haematol 2015;170:804-813.
112 Dhodapkar MV, Hussein MA, Rasmussen E, Solomon A, Larson RA, Crowley JJ, Barlogie B; United States Intergroup Trial Southwest Oncology Group: Clinical efficacy of high-dose dexamethasone with maintenance dexamethasone/alpha interferon in patients with primary systemic amyloidosis: results of United States Intergroup Trial Southwest Oncology Group (SWOG) S9628. Blood 2004;104:35203526.

113 Skinner M, Anderson J, Simms R, Falk R, Wang M, Libbey C, Jones LA, Cohen AS: Treatment of 100 patients with primary amyloidosis: a randomized trial of melphalan, prednisone, and colchicine versus colchicine only. Am J Med 1996;100:290-298.

114 Palladini G, Perfetti V, Obici L, Caccialanza R, Semino A, Adami F, Cavallero G, Rustichelli R, Virga G, Merlini G: Association of melphalan and high-dose dexamethasone is effective and well tolerated in patients with $\mathrm{AL}$ (primary) amyloidosis who are ineligible for stem cell transplantation. Blood 2004; 103:2936-2938.

115 Palladini G, Russo P, Nuvolone M, Lavatelli F, Perfetti V, Obici L, Merlini G: Treatment with oral melphalan plus dexamethasone produces long-term remissions in AL amyloidosis. Blood 2007;110:787-788.

116 Sanchorawala V, Seldin DC, Berk JL, Sloan JM, Doros G, Skinner M: Oral cyclic melphalan and dexamethasone for patients with AL amyloidosis. Clin Lymphoma Myeloma Leuk 2010;10:469-472.

117 Dietrich S, Schönland SO, Benner A, Bochtler T, Kristen AV, Beimler J, Hund E, Zorn M, Goldschmidt H, Ho AD, Hegenbart $\mathrm{U}$ : Treatment with intravenous melphalan and dexamethasone is not able to overcome the poor prognosis of patients with newly diagnosed systemic light chain amyloidosis and severe cardiac involvement. Blood 2010; 116:522-528.

118 Lebovic D, Hoffman J, Levine BM, Hassoun $\mathrm{H}$, Landau H, Goldsmith Y, Maurer MS, Steingart RM, Cohen AD, Comenzo RL: Predictors of survival in patients with systemic light-chain amyloidosis and cardiac involvement initially ineligible for stem cell transplantation and treated with oral melphalan and dexamethasone. Br J Haematol 2008;143:369-373.

119 Reece DE, Hegenbart U, Sanchorawala V, Merlini G, Palladini G, Bladé J, Fermand J-P, Hassoun H, Heffner L, Vescio RA, Liu K, Enny C, Esseltine D-L, van de Velde H, Cakana A, Comenzo RL: Efficacy and safety of once-weekly and twice-weekly bortezomib in patients with relapsed systemic AL amyloidosis: results of a phase $1 / 2$ study. Blood 2011;118:865-873.
120 Dubrey SW, Reece DE, Sanchorawala V, Hegenbart U, Merlini G, Palladini G, Fermand J-P, Vescio RA, Bladé J, Heffner LT, Hassoun H, Liu X, Enny C, Ramaswami P, Elsayed $\mathrm{Y}$, van de Velde $\mathrm{H}$, Mortimer S, Cakana A, Comenzo RL, Velcade RL; Can2007 Study Group: Bortezomib in a phase 1 trial for patients with relapsed AL amyloidosis: cardiac responses and overall effects. QJM 2011;104:957-970.

121 Mikhael JR, Schuster SR, Jimenez-Zepeda VH, Bello N, Spong J, Reeder CB, Stewart AK, Bergsagel PL, Fonseca R: Cyclophosphamide-bortezomib-dexamethasone (CyBorD) produces rapid and complete hematologic response in patients with AL amyloidosis. Blood 2012;119:4391-4394.

122 Kastritis E, Leleu X, Arnulf B, Zamagni E, Cibeira MT, Kwok F, Mollee P, Hájek R, Moreau P, Jaccard A, Schönland S, Filshie R, Nicolas-Virelizier E, Augustson B, Mateos M-V, Wechalekar A, Hachulla E, Milani P, Dimopoulos MA, Fermand J-P, Foli A, Gavriatopoulou M, Palumbo A, Sonneveld P, Johnsen HE, Merlini G, Palladini G: A randomized phase III trial of melphalan and dexamethasone (MDex) versus bortezomib, melphalan and dexamethasone (BMDex) for untreated patients with AL amyloidosis. Clin Lymphoma Myeloma Leuk 2015; 15:e59-e60.

123 Seldin DC, Choufani EB, Dember LM, Wiesman JF, Berk JL, Falk RH, O'Hara C, Fennessey S, Finn KT, Wright DG, Skinner M, Sanchorawala V: Tolerability and efficacy of thalidomide for the treatment of patients with light chain-associated (AL) amyloidosis. Clin Lymphoma 2003;3:241-246.

124 Dispenzieri A, Lacy MQ, Rajkumar SV, Geyer SM, Witzig TE, Fonseca R, Lust JA, Greipp PR, Kyle RA, Gertz MA: Poor tolerance to high doses of thalidomide in patients with primary systemic amyloidosis. Amyloid 2003;10:257-261.

125 Palladini G, Perfetti V, Perlini S, Obici L, Lavatelli $\mathrm{F}$, Caccialanza $\mathrm{R}$, Invernizzi $\mathrm{R}, \mathrm{Co}-$ motti B, Merlini G: The combination of thalidomide and intermediate-dose dexamethasone is an effective but toxic treatment for patients with primary amyloidosis (AL). Blood 2005;105:2949-2951.

126 Wechalekar AD, Goodman HJB, Lachmann HJ, Offer M, Hawkins PN, Gillmore JD: Safety and efficacy of risk-adapted cyclophosphamide, thalidomide, and dexamethasone in systemic AL amyloidosis. Blood 2007;109:457-464.

127 Venner CP, Gillmore JD, Sachchithanantham S, Mahmood S, Lane T, Foard D, Rannigan L, Gibbs SDJ, Pinney JH, Whelan CJ, Lachmann HJ, Hawkins PN, Wechalekar AD: A matched comparison of cyclophosphamide, bortezomib and dexamethasone (CVD) versus risk-adapted cyclophosphamide, thalidomide and dexamethasone (CTD) in AL amyloidosis. Leukemia 2014; 28:2304-2310. 
128 Dispenzieri A, Lacy MQ, Zeldenrust SR, Hayman SR, Kumar SK, Geyer SM, Lust JA, Allred JB, Witzig TE, Rajkumar SV, Greipp PR, Russell SJ, Kabat B, Gertz MA: The activity of lenalidomide with or without dexamethasone in patients with primary systemic amyloidosis. Blood 2007;109: 465-470.

129 Sanchorawala V, Wright DG, Rosenzweig M, Finn KT, Fennessey S, Zeldis JB, Skinner M, Seldin DC: Lenalidomide and dexamethasone in the treatment of AL amyloidosis: results of a phase 2 trial. Blood 2007;109: 492-496.

130 Moreau P, Jaccard A, Benboubker L, Royer B, Leleu X, Bridoux F, Salles G, Leblond V, Roussel M, Alakl M, Hermine O, Planche L, Harousseau J-L, Fermand J-P: Lenalidomide in combination with melphalan and dexamethasone in patients with newly diagnosed AL amyloidosis: a multicenter phase $1 / 2$ dose-escalation study. Blood 2010;116: 4777-4782.

131 Sanchorawala V, Patel JM, Sloan JM, Shelton AC, Zeldis JB, Seldin DC: Melphalan, lenalidomide and dexamethasone for the treatment of immunoglobulin light chain amyloidosis: results of a phase II trial. Haematologica 2013;98:789-792.

132 Dinner S, Witteles W, Afghahi A, Witteles R, Arai S, Lafayette R, Schrier SL, Liedtke M: Lenalidomide, melphalan and dexamethasone in a population of patients with immunoglobulin light chain amyloidosis with high rates of advanced cardiac involvement. Haematologica 2013;98:1593-1599.

133 Kastritis E, Terpos E, Roussou M, Gavriatopoulou M, Pamboukas C, Boletis I, Marinaki S, Apostolou T, Nikitas N, Gkortzolidis G, Michalis E, Delimpasi S, Dimopoulos MA: A phase $1 / 2$ study of lenalidomide with lowdose oral cyclophosphamide and low-dose dexamethasone (RdC) in AL amyloidosis. Blood 2012;119:5384-5390.

134 Kumar SK, Hayman SR, Buadi FK, Roy V, Lacy MQ, Gertz MA, Allred J, Laumann KM, Bergsagel LP, Dingli D, Mikhael JR, Reeder CB, Stewart AK, Zeldenrust SR, Greipp PR, Lust JA, Fonseca R, Russell SJ, Rajkumar SV, Dispenzieri A: Lenalidomide, cyclophosphamide, and dexamethasone (CRd) for light-chain amyloidosis: longterm results from a phase 2 trial. Blood 2012; 119:4860-4867.

135 Palladini G, Russo P, Milani P, Foli A, Lavatelli F, Nuvolone M, Perlini S, Merlini G: A phase II trial of cyclophosphamide, lenalidomide and dexamethasone in previously treated patients with AL amyloidosis. Haematologica 2013;98:433-436.

136 Specter R, Sanchorawala V, Seldin DC, Shelton A, Fennessey S, Finn KT, Zeldis JB, Dember LM: Kidney dysfunction during lenalidomide treatment for $\mathrm{AL}$ amyloidosis. Nephrol Dial Transplant 2011;26:881886.
137 Dispenzieri A, Dingli D, Kumar SK, Rajkumar SV, Lacy MQ, Hayman S, Buadi F, Zeldenrust S, Leung N, Detweiler-Short K, Lust JA, Russell SJ, Kyle RA, Gertz MA: Discordance between serum cardiac biomarker and immunoglobulin-free light-chain response in patients with immunoglobulin light-chain amyloidosis treated with immune modulatory drugs. Am J Hematol 2010;85:757-759.

138 Tapan U, Seldin DC, Finn KT, Fennessey S, Shelton A, Zeldis JB, Sanchorawala V: Increases in B-type natriuretic peptide (BNP) during treatment with lenalidomide in $\mathrm{AL}$ amyloidosis. Blood 2010;116:5071-5072.

139 Dispenzieri A, Buadi F, Laumann K, LaPlant B, Hayman SR, Kumar SK, Dingli D, Zeldenrust SR, Mikhael JR, Hall R, Rajkumar SV, Reeder C, Fonseca R, Bergsagel PL, Stewart AK, Roy V, Witzig TE, Lust JA, Russell SJ, Gertz MA, Lacy MQ: Activity of pomalidomide in patients with immunoglobulin light-chain amyloidosis. Blood 2012;119: 5397-5404.

140 Dubrey SW, Bilazarian S, LaValley M, Reisinger J, Skinner M, Falk RH: Signal-averaged electrocardiography in patients with AL (primary) amyloidosis. Am Heart J 1997; 134:994-1001.

141 Grogan M, Dispenzieri A: Natural history and therapy of AL cardiac amyloidosis. Heart Fail Rev 2015;20:155-162.

142 Kristen AV, Dengler TJ, Hegenbart U, Schonland SO, Goldschmidt H, Sack F-U, Voss F, Becker R, Katus HA, Bauer A: Prophylactic implantation of cardioverter-defibrillator in patients with severe cardiac amyloidosis and high risk for sudden cardiac death. Heart Rhythm 2008;5:235-240.

143 Varr BC, Zarafshar S, Coakley T, Liedtke M, Lafayette RA, Arai S, Schrier SL, Witteles RM: Implantable cardioverter-defibrillator placement in patients with cardiac amyloidosis. Heart Rhythm 2014;11:158-162.

144 Lin G, Dispenzieri A, Kyle R, Grogan M, Brady PA: Implantable cardioverter defibrillators in patients with cardiac amyloidosis. J Cardiovasc Electrophysiol 2013;24:793798.

145 Falk RH: Cardiac amyloidosis: a treatable disease, often overlooked. Circulation 2011; 124:1079-1085.

146 Gertz MA, Falk RH, Skinner M, Cohen AS, Kyle RA: Worsening of congestive heart failure in amyloid heart disease treated by calcium channel-blocking agents. Am J Cardiol 1985;55:1645.

147 Rubinow A, Skinner M, Cohen AS: Digoxin sensitivity in amyloid cardiomyopathy. Circulation 1981;63:1285-1288.

148 Falk RH, Dubrey SW: Amyloid heart disease. Prog Cardiovasc Dis 2010;52:347-361.
149 Grupper A, Park SJ, Pereira NL, Schettle SD, Gerber Y, Topilsky Y, Edwards BS, Daly RC, Stulak JM, Joyce LD, Kushwaha SS: Role of ventricular assist therapy for patients with heart failure and restrictive physiology: improving outcomes for a lethal disease. J Heart Lung Transplant 2015;34:1042-1049.

150 US Food and Drug Administration: Serious Adverse Events with Implantable Left Ventricular Assist Devices: FDA Safety Communication. August 5, 2015.

151 Freeman R: Clinical practice: neurogenic orthostatic hypotension. N Engl J Med 2008; 358:615-624.

152 Caccialanza R, Palladini G, Klersy C, Cena H, Vagia C, Cameletti B, Russo P, Lavatelli F, Merlini G: Nutritional status of outpatients with systemic immunoglobulin lightchain amyloidosis 1 . Am J Clin Nutr 2006; 83:350-354.

153 Caccialanza R, Palladini G, Klersy C, Cereda E, Bonardi C, Cameletti B, Montagna E, Russo P, Foli A, Milani P, Lavatelli F, Merlini G: Nutritional status independently affects quality of life of patients with systemic immunoglobulin light-chain (AL) amyloidosis. Ann Hematol 2012;91:399-406.

154 Sattianayagam PT, Lane T, Fox Z, Petrie A, Gibbs SDJ, Pinney JH, Risom SS, Rowczenio DM, Wechalekar AD, Lachmann HJ, Gilbertson JA, Hawkins PN, Gillmore JD: A prospective study of nutritional status in immunoglobulin light chain amyloidosis. Haematologica 2013;98:136-140.

155 Bodin K, Ellmerich S, Kahan MC, Tennent GA, Loesch A, Gilbertson JA, Hutchinson WL, Mangione PP, Gallimore JR, Millar DJ, Minogue S, Dhillon AP, Taylor GW, Bradwell AR, Petrie A, Gillmore JD, Bellotti V, Botto M, Hawkins PN, Pepys MB: Antibodies to human serum amyloid P component eliminate visceral amyloid deposits. Nature 2010;468:93-97.

156 Richards DB, Cookson LM, Berges AC, Barton SV, Lane T, Ritter JM, Fontana M, Moon JC, Pinzani M, Gillmore JD, Hawkins PN, Pepys MB: Therapeutic clearance of amyloid by antibodies to serum amyloid $\mathrm{P}$ component. N Engl J Med 2015;373:1106-1114.

157 Gertz MA, Landau HJ, Comenzo R, Seldin DC, Weiss BM, Zonder JA, Walling J, Kinney G, Koller M, Liedtke M: Cardiac and renal biomarker responses in a phase $1 / 2$ study of NEOD001 in patients with AL amyloidosis and persistent organ dysfunction (abstract). J Clin Oncol 2015;33(suppl):8514.

158 ClinicalTrials.gov: The VITAL Amyloidosis Study, a global phase 3, efficacy and safety study of NEOD001 in patients with AL amyloidosis. https://clinicaltrials.gov/ct2/show/ NCT02312206.

159 Ward JE, Ren R, Toraldo G, Soohoo P, Guan J, O’Hara C, Jasuja R, Trinkaus-Randall V, Liao R, Connors LH, Seldin DC: Doxycycline reduces fibril formation in a transgenic mouse model of AL amyloidosis. Blood 2011;118:6610-6617. 
160 Wechalekar A, Whelan C, Sachchithanantham S, Fontana M, Mahmood S, Foard D, Lane T, Lachmann HJ, Gillmore JD, Hawkins PN: A matched case control study of doxycycline added to chemotherapy for reducing early mortality in patients with advanced cardiac $\mathrm{AL}$ amyloidosis from the Alchemy Study cohort. Blood 2014;124:34853485.

161 ClinicalTrials.gov: Oral doxycycline administered as an adjunct to plasma cell directed therapy in light chain amyloidosis. https:// clinicaltrials.gov/ct2/show/NCT02207556? term $=$ NCT02207556\&rank $=1$.

162 ClinicalTrials.gov: Safety and effect of doxycycline in patients with amyloidosis. https:// clinicaltrials.gov/ct2/show/NCT01677286? term $=$ NCT01677286\&rank $=1$.

163 Hunstein W: Epigallocathechin-3-gallate in AL amyloidosis: a new therapeutic option? Blood 2007;110:2216.
164 Mereles D, Buss SJ, Hardt SE, Hunstein W, Katus HA: Effects of the main green tea polyphenol epigallocatechin-3-gallate on cardiac involvement in patients with $\mathrm{AL}$ amyloidosis. Clin Res Cardiol 2010;99:483-490.

165 Stefani M, Rigacci S: Beneficial properties of natural phenols: highlight on protection against pathological conditions associated with amyloid aggregation. Biofactors 2014; 40:482-493.

166 aus dem Siepen F, Buss SJ, Andre F, Seitz S, Giannitsis E, Steen H, Katus HA, Kristen AV: Extracellular remodeling in patients with wild-type amyloidosis consuming epigallocatechin-3-gallate: preliminary results of T1 mapping by cardiac magnetic resonance imaging in a small single center study. Clin Res Cardiol 2015;104:640-647.
167 Kristen AV, Lehrke S, Buss S, Mereles D, Steen H, Ehlermann P, Hardt S, Giannitsis E, Schreiner R, Haberkorn U, Schnabel PA, Linke RP, Röcken C, Wanker EE, Dengler TJ, Altland K, Katus HA: Green tea halts progression of cardiac transthyretin amyloidosis: an observational report. Clin Res Cardiol 2012;101:805-813.

168 ClinicalTrials.gov: A trial for the treatment of cardiac AL-amyloidosis with the green tea compound epigallocatechin-3-gallate (TAME-AL). https://clinicaltrials.gov/ct2/ show/NCT02015312?term=NCT02015312 \&rank=1.

169 Golden EB, Lam PY, Kardosh A, Gaffney KJ, Cadenas E, Louie SG, Petasis NA, Chen TC, Schönthal AH: Green tea polyphenols block the anticancer effects of bortezomib and other boronic acid-based proteasome inhibitors. Blood 2009;113:5927-5937. 